\title{
Estructuras narrativas en Watchmen. Apuntes para el análisis estilístico de la escritura de cómic
}

\author{
Julio César Iglesias Rodríguez
}

Julio César Iglesias Rodríguez es Licenciado en Historia por la Universidad de Oviedo. Está ultimando una tesis doctoral sobre las relaciones socioculturales entre Japón y Occidente desarrollada bajo una beca de investigación del Principado de Asturias. Ha colaborado en varios proyectos sobre memoria histórica y colectiva, así como en diversas publicaciones relacionadas. Actualmente escribe sobre historia y teoría del cómic en Zona Negativa y en la Revista Exégesis, y sobre análisis narrativo en su blog Nueve Párrafos. 


\section{Introducción y Objetivos}

Creo que profundizar en el estudio de las relaciones entre los recursos estéticos del cómic y la literatura podría ser tan provechoso para la narración gráfica como fue para el cine abundar en la observación de Eisenstein sobre las similitudes del montaje en paralelo de Charles Dickens y el de Griffith. En sentido estricto, todas las formas narrativas se basan en un sustrato técnico tan similar que un análisis estilístico ${ }^{1}$ puede subtender épocas, medios, géneros y, en general, toda división convencional. Así, nos encontramos casos de metáforas en el cómic, metonimias en el cine y planos de establecimiento en la literatura. Cualquier recurso artístico a disposición del narrador crea un efecto que puede replicarse, salvando las distancias de forma y lenguaje, en otros medios. Esta vecindad estilística no exige, en mi opinión, que se desdibujen las fronteras entre las diversas formas de arte narrativo, pero las aportaciones de autores que, como Harry Morgan, ${ }^{2}$ que abogan por considerar la narración gráfica una manifestación peculiar del hecho literario, enriquecen el debate acerca de la naturaleza del cómic.

Me temo, sin embargo, que gran parte de los críticos y autores que proclaman la condición literaria del cómic lo hacen porque piensan que, a partir de cierto nivel de calidad, algunas obras trascienden el género y se elevan hasta alcanzar un estadio cultural superior. Hay mucho que objetar a esta visión y el hecho de que empobrezca la perspectiva del analista no es el menor de los reproches: como dijo Robert Louis Stevenson, "los escritores de primera clase no tienen el monopolio del mérito literario". ${ }^{3}$ En todo caso, el alcance del fenómeno es amplio. Jan Baetens afirma que "cada vez más, la promoción exagerada que rodea a la novela gráfica tiene que ver con sus cualidades literarias". ${ }^{4}$ Muchos trabajos sobre Watchmen son explícitos al respecto. Van Ness (2010), Strobel (2008) o Flynn (2012) aluden en los títulos de sus ensayos a la condición literaria de Watchmen sin justificarla teórica ni empíricamente. La obra de Strobel Watchmen as a work of literature tiene la virtud de epitomar las premisas sobre las que gran parte de la industria cultural vincula novela gráfica y literatura.

Si analizamos una novela gráfica a la manera de una novela literaria y encontramos complejidad en su simbolismo y temas que comporten un significado profundo para la humanidad, entonces no hay duda de que la novela gráfica puede considerarse literatura. Examinaré y analizaré la novela gráfica Watchmen para descubrir si tiene la complejidad y temáticas necesarias para ser considerada literatura...

\footnotetext{
1 No pretendo en este artículo reivindicar ninguna escuela en concreto pero tampoco utilizo el término "estilístico" en sentido lato; comparto las aspiraciones genéricas de autores como Helmut Hatzfeld o Amado Alonso sin comulgar por ello con todas sus inferencias teóricas ni sociopolíticas, y sin desconocer que gran parte de los avances de la teoría literaria contemporánea son irrenunciables. Considero, en todo caso, que determinadas posiciones de la estilística y del formalismo pueden contribuir a enfatizar la importancia de la intencionalidad artística del autor y a situar en el centro del análisis sus decisiones estéticas. Me basta, por ejemplo, coincidir con Dámaso Alonso en que "el objeto de la estilística es la totalidad de los elementos significativos del lenguaje (conceptuales, afectivos, imaginativos)" (Alonso, D. Poesía española. Ensayo de métodos y limites estilísticos. Madrid, Editorial Gredos, 1951, p.584.) para valorar la relevancia de su pensamiento en el contexto del análisis de la narración gráfica.

2 Morgan, H. Principes des littératures dessinées. Angoulême, Éditions de l'An 2, 2003.

3 Stevenson, R.L. El arte de escribir. Santa Cruz de Tenerife, Artemisa Ediciones, 2006, p.19

4 Baetens, J. “Graphic Novels: Literature Without Text?” en English Language Notes, no 46, vol. 2 (2008), p. 77 http://racomics.pbworks.com/f/GN+Literature+Without+Text.pdf

5 Strobel, E. Watchmen as a work of literature. Oregón, Scholars Archive. Disponible on line en http:// ir.library.oregonstate.edu/xmlui/bitstream/handle/1957/8111/Strobel\%20thesis.pdf?sequence=1 Traducción propia.
} 
Es evidente que tal aproximación tiene poco que ver con los proponentes rigurosos de la novela gráfica pero, en la práctica, gran parte de los estudios sobre Watchmen intentan dignificar el cómic afirmando que su condición literaria se basa en la complejidad de su filosofía, la red simbólica, la contextualización histórica o los elementos paratextuales. Incluso Rafael Marín, ensayista justamente reconocido, afirma que Watchmen es una "obra maestra de la literatura de nuestro tiempo"6 sin aportar en su estudio un análisis que tenga que ver con la narrativa o la estilística de Watchmen. Se da, por tanto, la paradoja de que Watchmen es considerada una pieza literaria sin que haya mediado un análisis sobre las características narrativas de Moore y Gibbons.

Con este artículo pretendo, precisamente, contribuir a la comprensión de la técnica narrativa de Watchmen ${ }^{7}$ y, en el mejor de los casos, realizar alguna aportación de interés a la didáctica y estilística de la escritura del cómic. Prefiero hablar de "escritura" antes que de guión para sugerir con ello que el autor de cómic debe dominar todos los elementos relacionados con la narrativa, no solamente la trama o los personajes. La escritura de la narración gráfica es un proceso continuo en el que interactúan tropos de la lírica, procedimientos literarios y recursos fílmicos en una síntesis dialéctica que aún permanece relativamente inexplorada. Hago mías, a este respecto, las palabras de Edith Wharton:

\begin{abstract}
Para lo que aquí nos interesa, la forma quizá se podría definir como el orden —en el tiempo y según su importancia - en el que se agrupan los incidentes de la narración; y el estilo como el modo en que éstos se presentan, no sólo en el sentido estrecho del lenguaje, sino también, y más bien, en el de cómo son captados y reflejados por su instrumento, la mente del narrador, y restituidos con sus palabras. [...] Las palabras son los símbolos exteriores del pensamiento, y solo con su uso exacto puede el escritor mantener sobre su tema el estrecho y paciente dominio que "se sale con la suya" e impregna su obra de colores sólidos. ${ }^{8}$
\end{abstract}

Tales son las cuestiones sobre las que pretendo reflexionar a continuación.

\title{
1. Autor implícito y manipulación: Dos estrategias para legitimar la voz de Rors- chach
}

Abordemos, aunque sea de pasada, una de las precisiones más importantes de la teoría narrativa contemporánea: la que distingue entre el narrador y el autor implícito. ${ }^{9}$ Sabemos que Flaubert es el autor de Madame Bovary y también que un narrador omnisciente

\footnotetext{
${ }^{6}$ Marín, R. W de Watchmen. Palma de Mallorca, Dolmen Editorial, 2009, p.12. La aproximación de Rafa Marín es canónica, situando su énfasis muy especialmente en la simetría. También Mervi Miettinen (2006) analiza la composición de Watchmen, aunque le interesan especialmente los agregados metaficcionales y las citas literarias. De hecho, el título del estudio de Miettinen, "Framing a Fearful Symmetry", parafrasea sin citarlo el ensayo de Northrop Frye A Fearful Symmetry, un estudio sobre William Blake que, como es sabido, es uno de los autores que más han influido en la obra de Alan Moore.

7 Que es, por suerte, uno de los pocos ámbitos en los que se puede aportar algo a los estudios sobre Watchmen, seguramente el cómic más y mejor leído de todos los tiempos. Y aún así, todos los años aumenta el corpus bibliográfico con nuevos enfoques. Merece la pena citar, por la multitud de perspectivas incluidas, uno de los trabajos más recientes, Radiografías de una explosión, obra colectivo publicada en 2013 por Modernito Books. No es ninguna sorpresa que la obra conste de doce ensayos.

8 Warthon, E. El arte de la ficción. Palma de Mallorca, El Barquero, 2012, p. 29.

${ }^{9}$ El concepto fue acuñado por Wayne Booth, y desarrollado por múltiples autores entre los que destaca la aportación de Seymour Chatman
} 
nos informa de la trama del relato. Su voz se funde, en ocasiones, con la consciencia de Emma Bovary, en otras fluye irrestricta por encima de todos los personajes para posarse, brevemente, en la percepción de alguno en concreto. Pero es Flaubert quien decide a cada momento dónde está colocado el narrador, cuánto sabe y cuánto sabe el espectador. También decide qué objetos mostrarnos y cuáles ocultarnos, cuándo revelarlos, hacia dónde mira un personaje y qué es lo que escapa a su percepción. En la escena final de El Padrino (Coppola, 1972), el director decide mostrarnos a Michael Corleone solo a través de los ojos de su esposa y revelarnos así que Michael ya no es capaz de valorar sus propios actos. Las decisiones que toma el autor para modular la percepción del espectador atendiendo a las necesidades de su historia construye una mirada peculiar que determina la forma, siempre única, del relato.

¿Dónde podemos localizar al autor implícito de Watchmen? En la mirada selectiva de Alan Moore, ${ }^{10}$ en la forma en que modula el relato para que se ajuste a sus necesidades y consiga transmitir en cada momento los efectos perseguidos. La escena de apertura de Watchmen, es, a este respecto, modélica. Hace avanzar la trama - el Comediante ha sido asesinado-y garantiza, con economía de medios, la verosimilitud del narrador explícito, Rorschach. A continuación comentaremos las estrategias con las que Moore manipula el relato para construir la pátina de fiabilidad que acompaña a Rorschach durante toda la obra.

Debo dar por hecho que todos los lectores conocen la historia de Watchmen. Edward Blake, más conocido como el Comediante, ha sido asesinado. En las primeras páginas del cómic dos policías están buscando pistas en su casa. Vemos, mientras tanto, algún flashback de la muerte de Blake, que no fue capaz de presentar resistencia. De la charla de los policías inferimos que el Comediante, pese a su avanzada edad, se conservaba en buena forma; su foto junto a Gerald Ford evidencia que estaba bien conectado con las más altas esferas políticas. Los policías bromean sobre la foto y descartan que el vicepresidente sea sospechoso del asesinato: "no es su estilo" dice uno de ellos. Tras salir de la casa comentan que la investigación debe continuar pero con discreción, para no tener problemas con los héroes retirados. Aún no han descubierto nada.

Cae la noche. Aparece Rorschach, uno de los pocos héroes en activo, dispuesto a investigar la muerte de su antiguo compañero. Ya habíamos escuchado sus pensamientos en un diario que actuará de hilo conductor durante buena parte del relato. Rorschach es una especie de Travis Bickle llevado al extremo. Como el personaje de Taxi Driver (Scorsese, 1976), se lamenta de la podredumbre de la ciudad, corrompida por el sexo y la violencia. Rorschach es más explícito que Bickle en sus planteamientos racistas y homófobos. Guarda, eso sí, un respetuoso silencio mientras recorre el piso del Comediante. Pronto descubre un doble fondo en un armario del dormitorio de Blake, y en él, el traje del Comediante. Notamos por los movimientos de Rorschach que es sigiloso, preciso. Profesional.

En este momento ya no nos importan las ideas políticas de Rorschach, ni sus métodos violentos. Tampoco dudaremos de su percepción de la realidad cuando sepamos que su

\footnotetext{
10 Asumiré, por comodidad y convención, que Alan Moore es el responsable de las decisiones que competen al guión. No ignoro por ello que la aportación de Dave Gibbons fue fundamental en todos los pasos de la construcción del relato, desde la concepción hasta la selección del encuadre. Pero concentrarse en discernir entre los méritos de uno y de otro complicaría en exceso la estructura expositiva del artículo.
} 


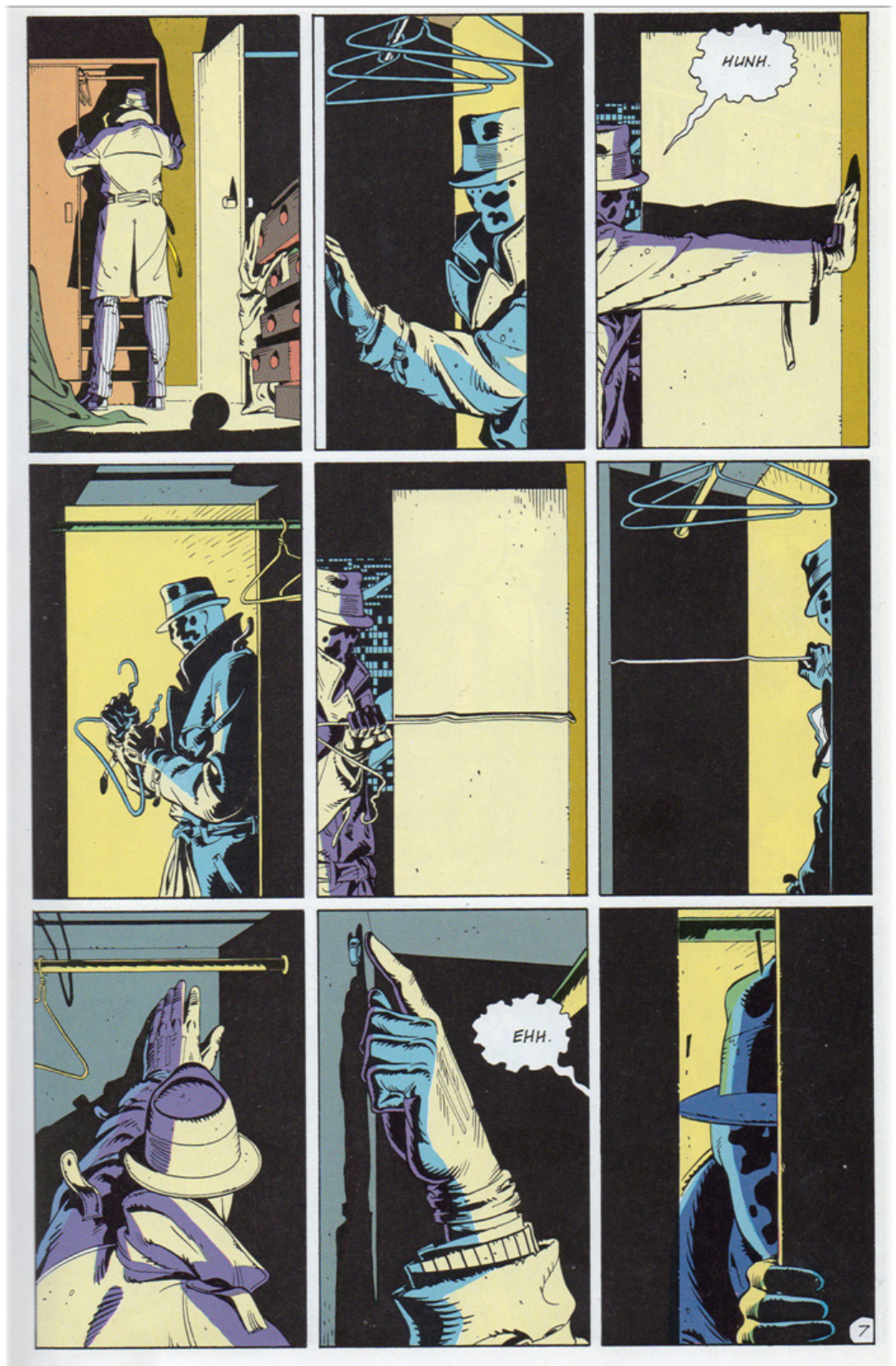

FIG. 1. Watchmen. Alan Moore y Dave Gibbons (1986-87). Cap. I, p. 7.

mente es, cuando menos, inestable. Alan Moore ha establecido la verosimilitud del narrador a través de una oposición estructural extremadamente simple que demuestra un conocimiento preciso de lo que es el protagonista de la ficción clásica o arquitrama. ${ }^{11}$ Hay dos motivos por los que confiamos en Rorschach. El primero ya lo hemos visto: Rorschach demuestra ser capaz de conducir la trama. Los policías se marchan del piso sin encontrar pistas pero él encuentra el traje del Comediante y, mucho más importante, nos lo enseña. Los lectores atribuimos a Rorschach, inconscientemente, el mérito de hacer avanzar las revelaciones de la trama. Nada de lo que haga el personaje podrá cambiar esa primera vinculación estructural.

\footnotetext{
${ }^{11}$ Utilizo esta expresión, popularizada por Robert McKee para referirme a narrativas que utilizan modelos tradicionales, esto es, los que se basan en la evolución del personaje a través de una trama organizada según la disposición de peripecias clásica (inicio-medio-final) que se remonta hasta la Poética de Aristóteles.
} 
Pero la escena está trucada. Cuando los policías rastrean el piso del Comediante el narrador visual - recordemos, el autor implícito - nos oculta el dormitorio. Sin embargo, lo primero que hace Rorschach es entrar al dormitorio en donde encuentra el traje del Comediante. Además, ya se ha dicho, los policías hablan de forma irreverente mientras que Rorschach guarda un respetuoso silencio. Al salir del piso los policías buscan la manera de continuar la investigación de forma que ello no les cause problemas profesionales. Rorschach no piensa en los problemas que la justicia y la verdad puedan causarle: sencillamente las persigue como un justiciero incansable. Un sencillo sistema de oposiciones morales y procedimentales que resalta la dignidad de Rorschach y rebaja la de los policías.

El segundo motivo por el que confiamos en Rorschach se deriva de la escena de apertura

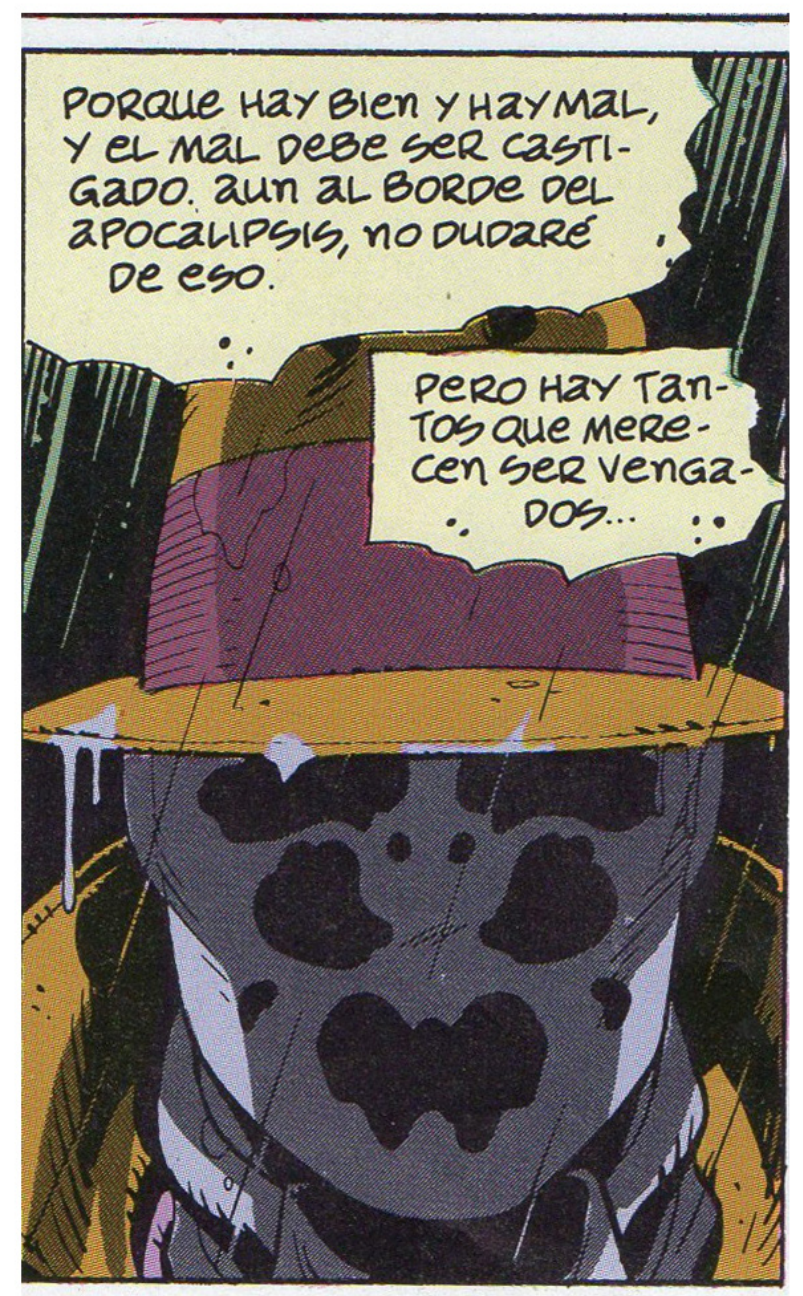

FIG. 2. Watchmen. Alan Moore y Dave Gibbons (1986-87). Cap. I, p. 24.

pero culmina en la sexta viñeta de la página 24, punto exacto en el que concluye la presentación del personaje.

Rorschach tiene una misión. Lucha por valores universales. A partir de esta viñeta sospechamos - no sin motivos - que este personaje, aunque odie a los comunistas y los homosexuales, odia más aún la maldad y la injusticia. La simpatía del espectador por los motivos universales está garantizada. Es un truco que ha utilizado Clint Eastwood hasta 
la saciedad. Su personaje en Gran Torino (Eastwood, 2008) trata con estereotipos racistas a sus vecinos vietnamitas pero, cuando llega la hora de la verdad, el valor "racismo" es inferior al valor "amistad".

Dos trucos sencillos solo en apariencia permiten a Moore falsear la voz de Rorschach para convertirla en la única autorizada: ve lo que otros no ven ${ }^{12}$ — por tanto, estamos obligados a aceptar su mirada - y siente la justicia como un impulso primario, con lo que los aspectos censurables de su pensamiento pasan a un segundo plano. La estructura narrativa manipula el relato y convierte a Rorschach en el verdadero héroe de Watchmen. De hecho, es el único héroe.

\section{ACEPTAR LO INTOLERABLE: No penséis en la mujer vietnamita}

En la mejor ficción no hay buenos ni malos, solo personajes que hacen lo que pueden para triunfar en su esquina de la trama. El lector sensible reaccionará con desagrado si nota que su héroe lucha contra un malvado sin matices. ${ }^{13}$ Eso no le impedirá disfrutar de un buen relato pero jamás alcanzará el placer que se deriva de una oposición que enriquezca, al mismo tiempo, al protagonista y a su adversario. He ahí una de las tareas más hermosas del autor narrativo, que puede convertir la lucha entre protagonista y antagonista en una relación de aprendizaje y significado.

Eso no quiere decir que los espectadores estemos dispuestos a aplaudir cualquier acto perverso que contribuya a la trama salvo, claro está, que nos engañen para que lo hagamos. Aceptamos que el doctor Hannibal Lecter se coma a gente y celebramos su fuga aunque le haya arrancado la piel de la cara a un policía inocente. Aunque otros inocentes vayan a ser parte de su cena en un futuro próximo. Aceptamos que Roy Batty le saque los ojos a un comerciante en Blade Runner (Scott, 1982) y lloramos que se apague su vida artificial. ¿Por qué asumimos actos que no encajan en nuestra escala de valores? La respuesta es mucho más compleja que aforismos de moda tipo "salva al gato"14 y nos llevaría a un análisis profundo del rol de Lecter y Batty pero baste señalar el aspecto clave de su caracterización: son fascinantes. Roy Batty es un androide que sueña con vivir un día más. ¿Cómo podríamos no amar a un ser artificial atormentado por el miedo al olvido? ${ }^{15}$ Hannibal Lecter, por su parte, es un caníbal culto y refinado que, como sucedía con Rorschach, es el único personaje de El Silencio de los Corderos (Demme, 1991) capacitado para hacerse cargo de la investigación. Insisto: los espectadores concedemos nuestra simpatía a cualquier personaje al que se le conceda el poder exclusivo de resolver la trama.

\footnotetext{
12 Hay muchos indicios de que la trama de investigación de Watchmen es un callejón sin salida diseñado únicamente para poner en comunicación y conflicto a los personajes. Uno de esos indicios es el hecho cierto de que los lectores nunca disponen de las piezas del puzzle; solo pueden ver su contorno una vez que los personajes lo han desvelado.

13 A no ser que la historia consista, precisamente, en la lucha contra un villano sin matices, como sucede en las películas de James Bond. En todo caso, rara vez se ha visto una obra maestra organizada en torno a la oposición de un bien y un mal absolutos.

14 Principio popularizado por Blake Snyder, guionista y gurú de cine. "Salva al gato" refiere a la conocida técnica por la que un personaje hace algo positivo para poner de su parte al espectador y predisponerle para que acepte ulteriores acciones negativas. Es una técnica tan difundida que ya forma parte de los conocimientos mínimos del guionista de cine pero su manejo requiere mayor sutilidad de la que sugieren Snyder y otros autores de manuales de consumo rápido.

15 De hecho, le amamos demasiado. La red de personajes de Blade Runner está irremediablemente desequilibrada por ese motivo.
} 


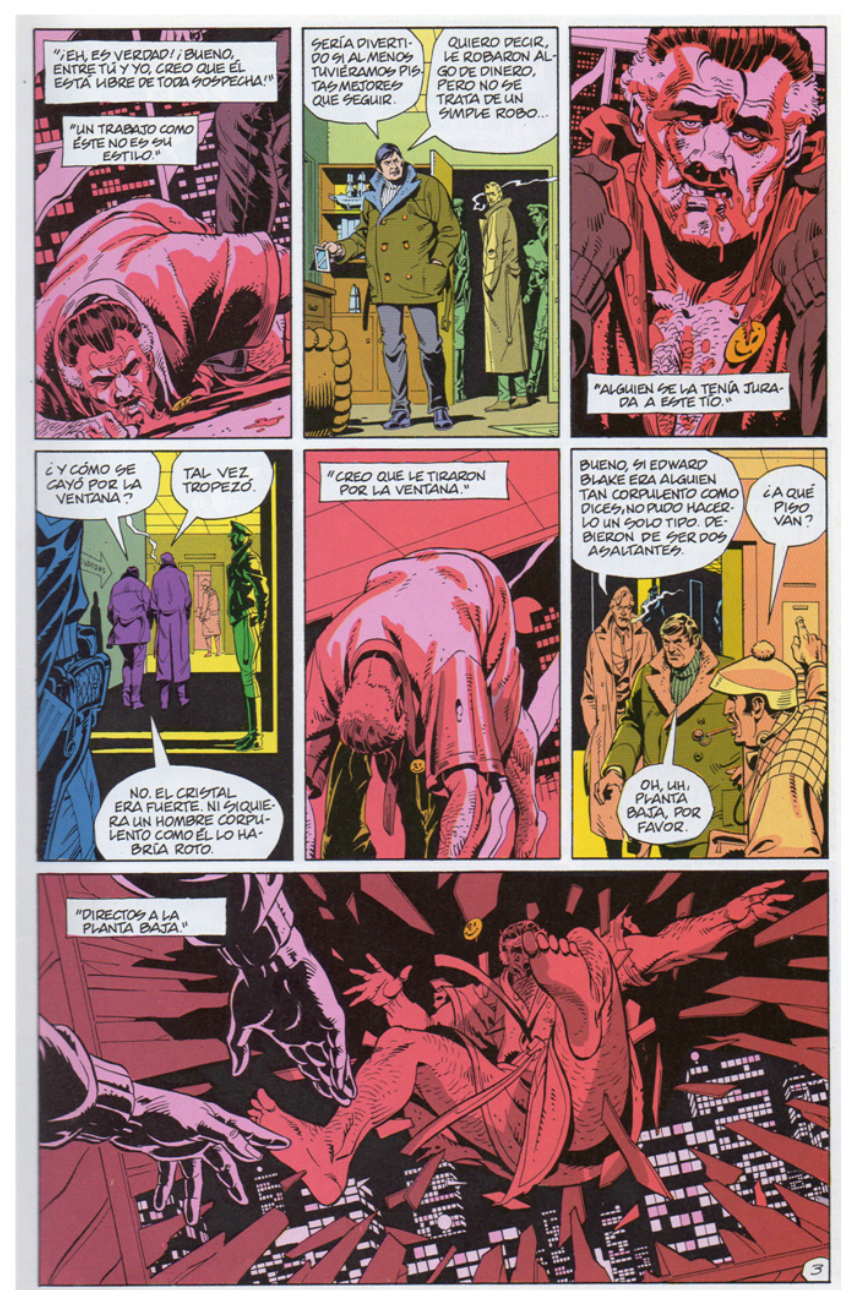

FIG. 3. Watchmen. Alan Moore y Dave Gibbons (1986-87). Cap. I, p.2.

La fascinación es un prerrequisito para aceptar los actos malvados de un personaje pero no es argumento suficiente. Por supuesto que el Comediante es un personaje fascinante, y lo es a muchos niveles, pero el éxito de su caracterización tiene que ver con la estrategia expositiva de Moore que, de nuevo, nos proporciona una pauta tan elegante como canónica.

Conocemos a Blake por los ecos de su muerte. En esa escena Moore pulsa una tecla poderosa: el drama crepuscular Era un hombre maduro pero con aspecto de ser capaz de ofrecer resistencia. Todos queremos que el héroe triunfe en su última aventura y, en este caso, sentimos que nos han hurtado el glorioso momento en que el boxeador veterano levanta su rostro ensangrentado, enseña los puños y se prepara para la batalla definitiva. Gracias a esta presentación elíptica en la que no vemos la lucha sino las trazas lejanas de una soberana paliza hacemos nuestra la rabia de Rorschach cuando descubre que el Comediante ha sido asesinado. No lamentamos la muerte del hombre, al que aún no conocemos, sino la aventura que se nos ha negado.

He aquí, por cierto, una de las diferencias más sensibles entre el cómic y su versión fílmica. Zack Snyder se inventa la pelea entre el Comediante y Veidt y nos la muestra en un despliegue de ataques, contraataques y crujir de huesos. Es una decisión muy deficiente cuyas implicaciones afectan a toda la estructura de la película. La elipsis 
del cómic tiene valor creativo, como lo tiene la ocultación en general. Un autor más comprometido con su arte ${ }^{16}$ habría reconstruido Watchmen con su propio lenguaje, alterando las viñetas allí donde le hiciera falta — ajeno a la veneración ritual de Snyder por la viñeta - respetando, probablemente, el pulcro silencio de los flashbacks. Costa Gavras, por ejemplo, nunca expone el interior de los campos de concentración en Amén (Gavras, 2002). En su lugar muestra el recorrido de los trenes que cruzaban Alemania, yendo y viniendo de los campos de concentración. Cada vez que vemos un tren sabemos que viaja cargado de víctimas o de cadáveres, así que la imagen se convierte en pura sugerencia, metáfora que evoca horrores más terribles de los que podría contener la pantalla. La elipsis reiterada crea símbolos más potentes que una exhibición inoportuna.

En el segundo capítulo, "Amigos Ausentes", Moore sube las apuestas y comienza una carrera frenética que nos interroga sobre los límites de la ética y la moral Tras asesinar al Comediante hurtándonos el derecho a disfrutar de su resistencia nos resume la vida y personalidad de Edward Blake. Abreviemos: era un ser deleznable, "prácticamente un nazi”, en expresión de Adrian Veidt. En este capítulo, dedicado al pasado del Comediante,
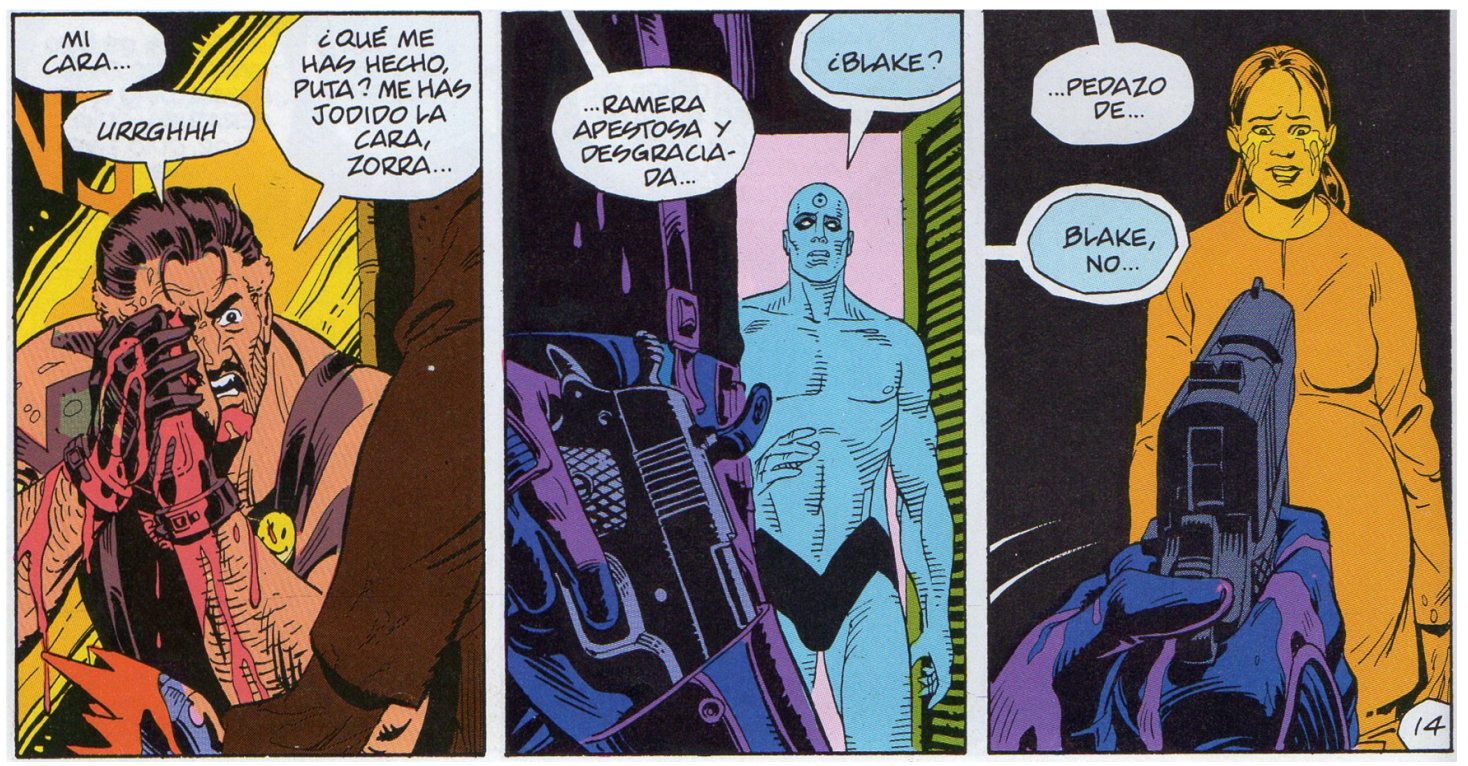

FIG. 4. Watchmen. Alan Moore y Dave Gibbons (1986-87). Cap. II, p. 14.

le vemos intentar violar Sally Júpiter, reprimir con extrema violencia una manifestación civil y, en el colmo del desafío al lector, asesinar a una mujer embarazada. Embarazada del hijo del Comediante.

Pero Alan Moore siempre juega con las cartas marcadas. Seamos sinceros. ¿Odiamos al Comediante? Ha asesinado a una mujer embarazada de su propio hijo ¿Celebramos la muerte del Comediante como un acto de justicia poética? Dudo que alguien responda que sí: rara vez deseamos perder a un personaje tan fascinante. Pero aunque su visión

\footnotetext{
${ }^{16}$ La versión fílmica de Zack Snyder toma alguna decisión interesante que nos podría ayudar a discutir alguna de las pocas - pero letales- deficiencias de Alan Moore. Me refiero, muy especialmente, a la acertada modificación del final. Lamentablemente, la cuestión tiene tanto alcance que me haría consumir más espacio del razonable para abordarla.
} 


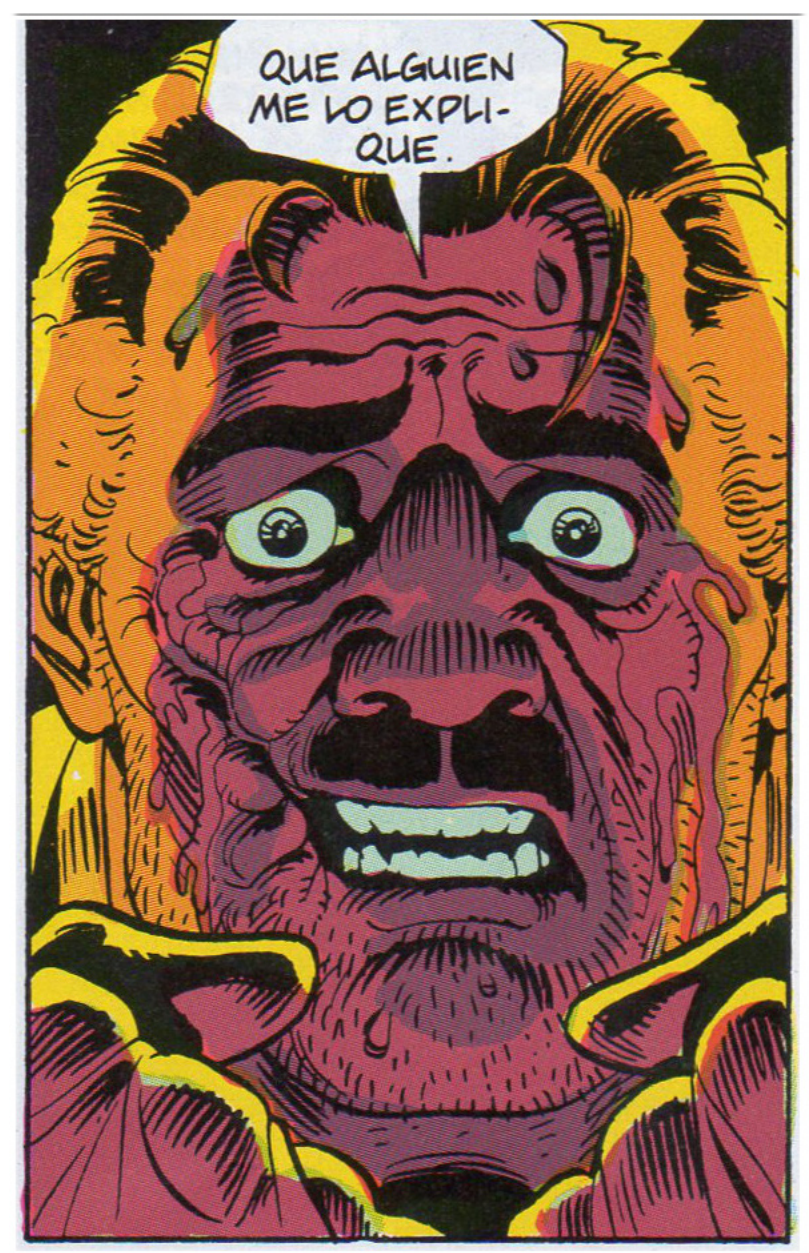

FIG. 5. Watchmen. Alan Moore y Dave Gibbons (1986-87). Cap. II, p. 23.

del mundo perversa y desencantada resulte atractiva, la fuerza de su caracterización no sería suficiente para hacernos cómplices involuntarios de su brutalidad. El Comediante es un instrumento de Alan Moore. En el segundo capítulo le hemos visto cometer varias tropelías sin arrepentirse. Era joven y estaba lleno de energía. Pero al final del capítulo se presenta en el hogar de Moloch, su antiguo archienemigo, un viejo débil y moribundo. E1 Comediante llora. Balbucea incoherencias acerca de un plan terrible, increíblemente maligno. ¿Quién podría concebir un plan tan maléfico que pueda hacer llorar a un hombre que disparó sin pestañear a la mujer que llevaba en su vientre a su propio hijo?

De pronto las crueles acciones del Comediante parecen quedar lejos. Su carga ética no se ha invertido, pero el poder narrativo del personaje ha sido rebajado por la irrupción, aún misteriosa, de un antagonista que está muy por encima de su poder. Es uno de los trucos más viejos de la ficción: si un personaje malvado es superado ampliamente por un personaje mucho más cruel, la maldad primera se relativiza y deviene tolerable.

Recordemos la escena de apertura de Watchmen y lamentemos, otra vez, que Zack Snyder no respetara su magnífico diseño. Alan Moore nos oculta la pelea entre el Comediante y su asesino pero, páginas después, se recrea en sus lágrimas con un primerísimo plano. Edward Blake está atrapado entre la elipsis de su muerte y la certeza de sus lágrimas. El Comediante sin escrúpulos es, a efectos narrativos, otra víctima de la trama. El contorno de la mujer vietnamita se diluye en el pasado... 


\section{CONSCIENCIA Y ESTRUCTURA NARRATIVA: Estilo indirecto libre}

No hay mayor testimonio de la maestría de un artista narrativo que sus esfuerzos por ajustar la forma al contenido. La voz de Henry James nos hace descender hasta la compleja comprensión infantil de Maisy. Los blancos primeros planos de Dreyer en Juana de Arco (Dreyer, 1932) penetran en el mundo interior de la condenada. Watchmen altera la textura de su narrativa para encontrar el tono y el ritmo adecuados a las emociones de sus personajes. Hasta ahora hemos visto algunos mecanismos de construcción del personaje

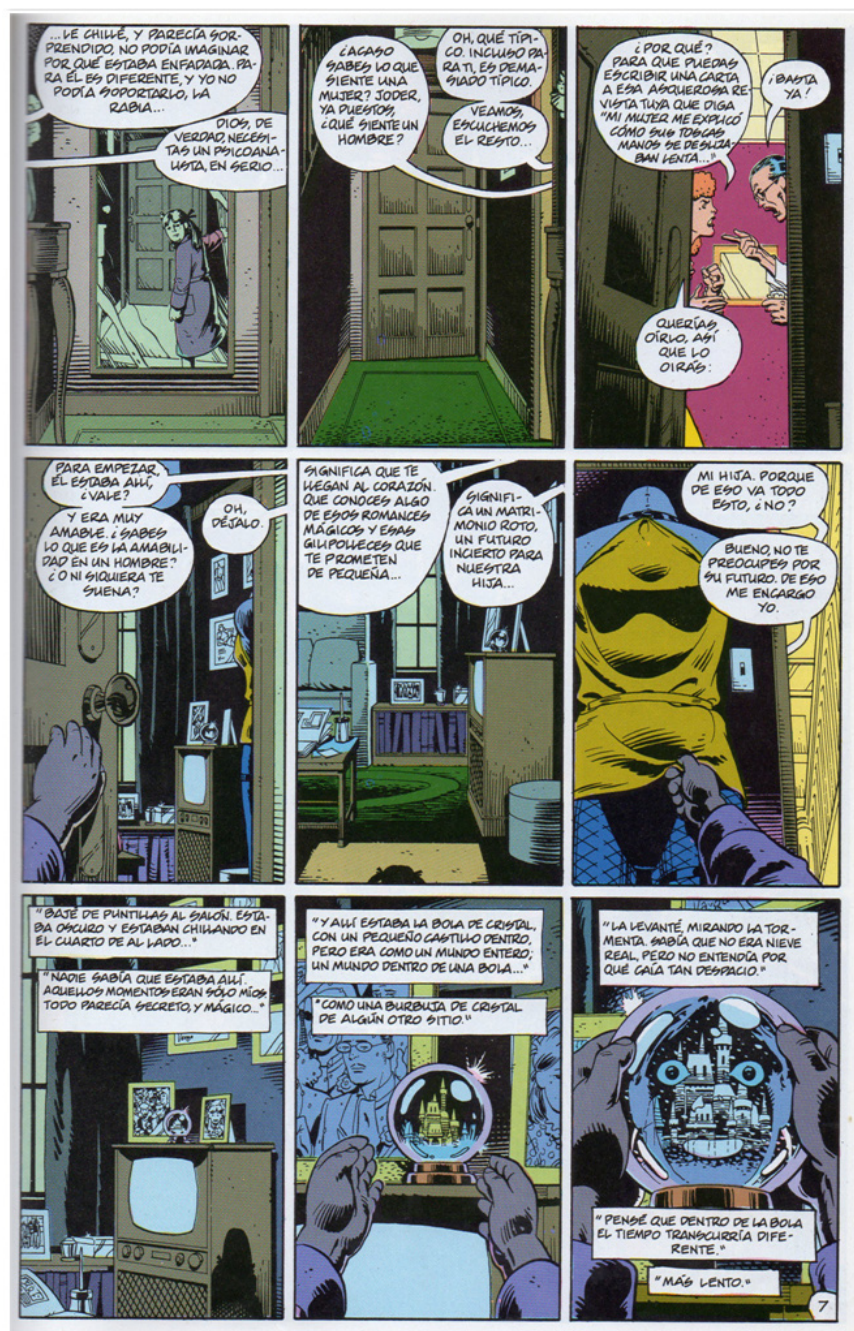

FIG. 6. Watchmen. Alan Moore y Dave Gibbons (1986-87). Cap. IX, p. 7.

que tienen que ver con la trama en tanto concatenación de hechos pero Alan Mooore es un gran creador porque sus guiones trabajan a varios niveles. Un autor competente ajusta la estructura visual de la página a las peripecias exteriores de la trama. Un autor genial se preocupa también de ajustar la estructura visual a las peripecias interiores de sus personajes.

En esta página asistimos a una escena de la infancia de Laurie. En la primera viñeta la pequeña aparece reflejada en un espejo; en la tercera atisba a través de la puerta entreabierta la discusión de su madre y su padre adoptivo. En el resto de las viñetas sabemos que la discusión prosigue pero la mirada es indirecta, casi oblicua. De no ser por las manos de 


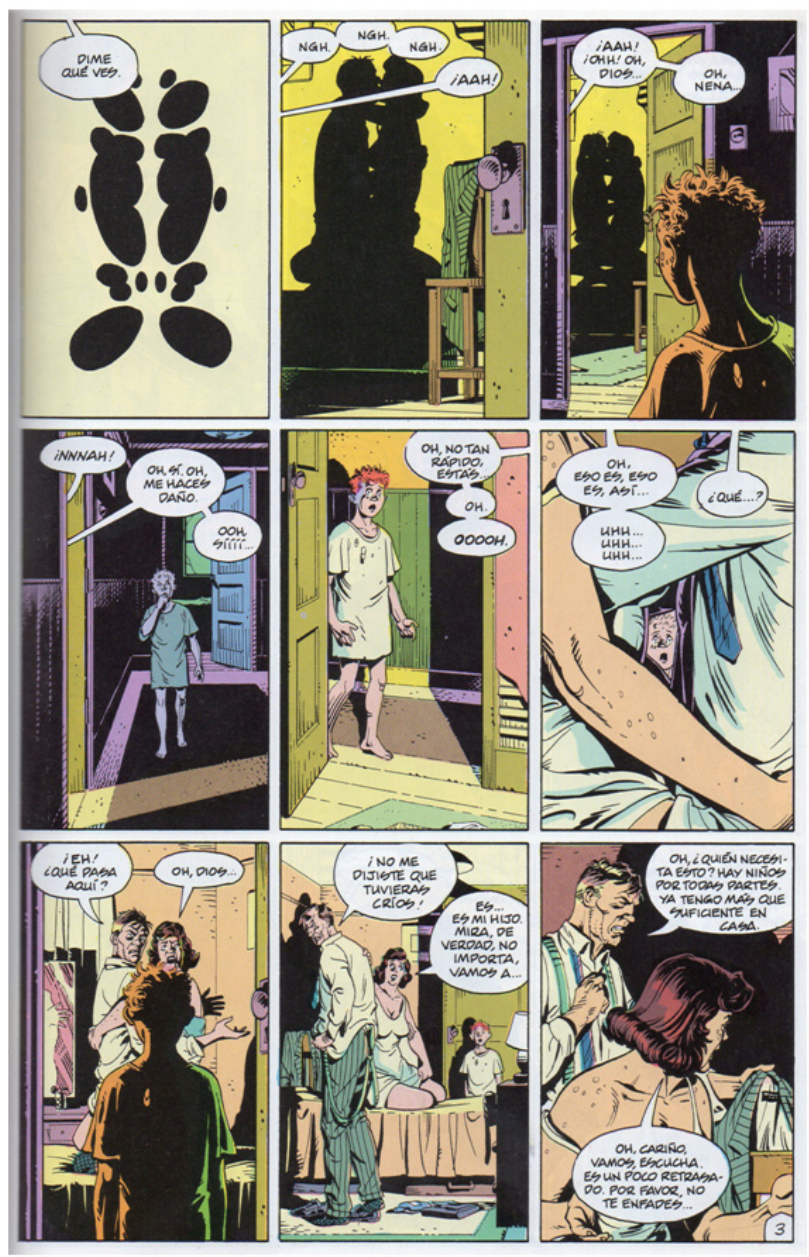

FIG. 7. Watchmen. Alan Moore y Dave Gibbons (1986-87). Cap. VI, p. 3.

la niña se trataría de campos vacíos aunque, en este caso, no intensifican la escena sino que relajan su intensidad. El narrador — vale decir el autor implícito- es delicado, como si temiera estorbar la inocente percepción de Laurie, que vive una revelación imprevista, un momento mágico, tan frágil como la bola que coge entre sus manos y que terminará rompiéndose en la página siguiente. Casi podemos notar el silencio que se impone al ruido de la pelea de sus padres.

Veamos otra escena de infancia.

Este es el trauma fundacional de Rorschach. ¡Qué diferencia con el narrador de la escena de Laurie! La cámara es indiscreta, vulgar, morbosa. Si antes atisbábamos algo desde una puerta entreabierta ahora las puertas están abiertas de par en par. El contraplano en proximidad de la sexta viñeta es toda una declaración de intenciones: había alternativas igualmente apropiadas pero el narrador pretende aproximarnos a la crudeza de la experiencia de Kovacs. El acercamiento se integra orgánicamente con el arco de personaje de Rorschach, ayudándonos a comprender su psique alterada y la forma en que ve el mundo.

Alan Moore adapta su lenguaje al mundo interior de los personajes. El narrador es delicado con Laurie, nos ofrece su trauma a través de un lenguaje visual indirecto, derivativo. 
Es un modo de contar coherente con una revelación que, en ese momento, Laurie aún no comprende. Además no es una experiencia ni mucho menos tan brutal como la de Rorschach. En el caso de éste, el narrador cambia de tono y se vuelve áspero, acerca los planos a la carne, se recrea con la obscenidad. Laurie había enterrado los recuerdos - y las dudas- sobre su pasado y el narrador muestra su memoria a través de rendijas y puertas entreabiertas. El narrador de Rorschach derriba toda barrera porque la memoria de Kovacs no se oculta el pasado sino que está marcada por él.

Nada queda al azar en la buena narración y no hay ámbito que pueda contemplarse si no es en su relación dialéctica con la totalidad del relato. Al cómic se le puede aplicar la metáfora con la que Henry James se refiere al arte de la escritura: "La 'historia' y la novela, la idea y la forma, son la aguja y el hilo, y jamás he oído hablar de un gremio de sastres que recomendara el empleo del hijo sin aguja, ni de aguja sin hilo."17

\section{SANGRE DE PÁJARO: El montaje como productor de contenido metafórico}

El estilo indirecto libre, esto es, la fusión entre la consciencia del personaje y la voz del autor implícito, nos abre la puerta a considerar recursos estéticos y estilísticos que, siendo propios de la literatura, no le resultan ajenos al cine ni al cómic. Tanto los planos como las viñetas pueden cumplir funciones análogas a las metáforas, las metonimias, el hipérbaton o la sinécdoque. En el caso de la metáfora hay relación directa entre el montaje de atracciones de Eisenstein ${ }^{18}$ y la transferencia de significado inherente al tropo.

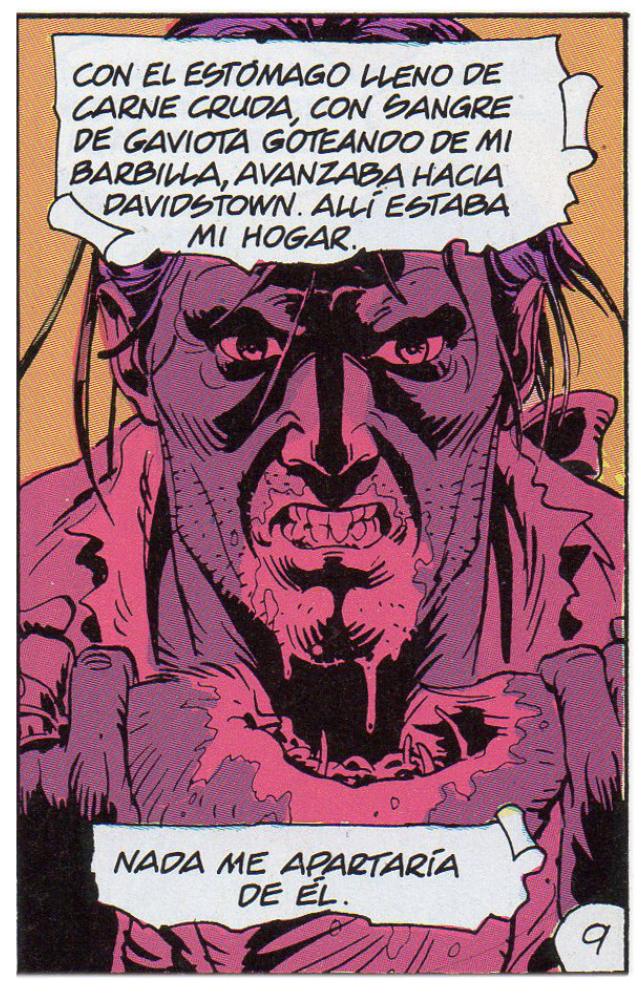

FIG. 8. Watchmen. Alan Moore y Dave Gibbons (1986-87). Cap. VII, p. 9.

\footnotetext{
17 James, H. "El arte de la ficción”, en El futuro de la novela, Madrid, Taurus, 1975, p. 32.

18 Podría añadirse a Pudovkin o a Tarkovski pero las diferencias entre los cineastas soviéticos, aunque sutiles, son lo suficientemente profundas como para distinguir, dentro de una tradición compartida, diferentes concepciones del montaje.
} 
Esta es la última viñeta de la página 9 del quinto capítulo de Watchmen, "Terrible simetría". El personaje es el náufrago que protagoniza "Relatos del navío negro", subtrama metaficcional que proporciona paralelismos y contrastes durante gran parte del cómic. En esta página el náufrago construye una barca con los cadáveres de sus antiguos compañeros y se dispone a cruzar el océano. Vemos en su rostro sombrío que este hombre ha tomado una decisión irrevocable y no dudamos que atravesará cualquier infierno para volver a su hogar. También sospechamos que, aunque logre su objetivo, jamás volverá a ser el mismo.

Pasemos la página.

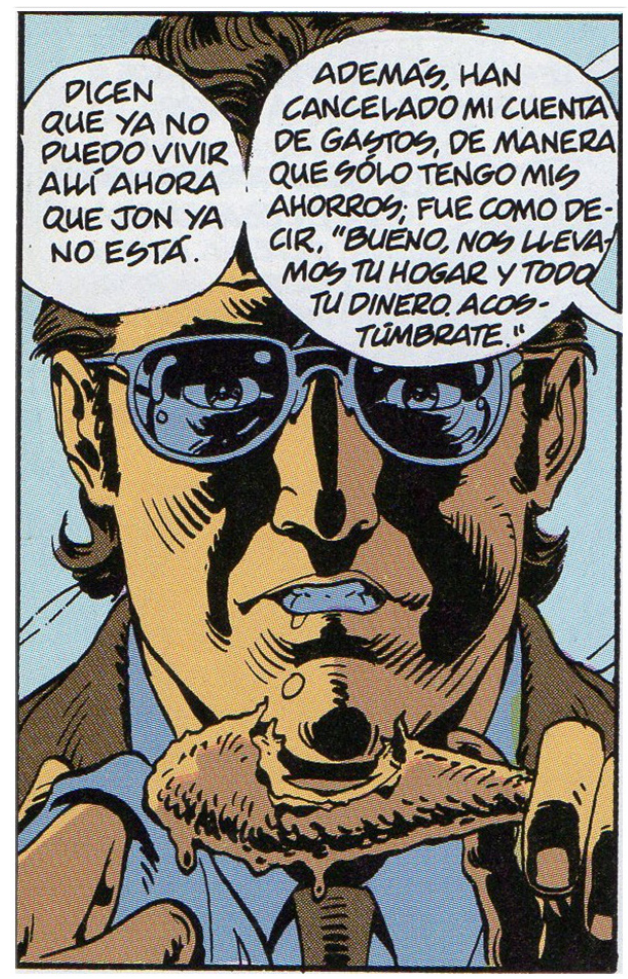

FIG. 9. Watchmen. Alan Moore y Dave Gibbons (1986-87). Cap. viI, p. 10.

Esta es la primera viñeta de la página 10. Las sombras del rostro del náufrago cubren ahora el de Dan Dreiberg, alias el Búho, héroe retirado y cuarentón sin grandes aspiraciones. El efecto es análogo al de una metáfora, aunque la forma sea la del símil. Etimológicamente, "metáfora" surge de la unión entre dos voces griegas, meta (fuera, exterior) y pherei, que significa transferencia. En este caso la transposición de significado entre una viñeta y otra se condensa en la carne de ave, el término de comparación que aglutina la carga simbólica de la analogía visual. El náufrago que devora las entrañas del cuerpo vivo de la gaviota traslada la oscuridad de su gesto a Dan Dreiberg, que saborea un muslo de pollo. Quizá de pavo. El procedimiento conecta un relato con el otro, asegura la continuidad mediante una interacción simbólica y favorece que la transición entre escenas sea fluida.

Podríamos dejar el análisis aquí. Ya hemos identificado el mecanismo de transferencia metafórica que asegura la continuidad del relato. El autor comunica la esfera simbólica de la subtrama del náufrago con la trama principal a través de un símil cuyo efecto estético y narrativo es tan impactante como apropiado. Pero apenas hemos rascado la 
superficie. Demos un paso atrás para precisar algo sobre el concepto de metáfora. Paul Ricoeur apunta que debemos considerar metáfora "al enunciado entero con su sentido nuevo y no sólo a la desviación paradigmática que focaliza en una palabra la mutación de sentido de ese enunciado." ${ }^{19}$ En el caso que nos ocupa hemos asumido - sin obviar las reservas que merece atribuir categorías verbales a la narración visual— ${ }^{20}$ que la "palabra" que focaliza la mutación de sentido es la carne de ave. El "enunciado completo" sería, en este caso, el símil entre Dan Dreiberg y la terrible imagen del náufrago devorando las entrañas de una gaviota.

Comencemos a profundizar en el análisis intentado situar esta viñeta en el arco de transformación del protagonista. ¿Por qué las sombras transforman el rostro de Dreiberg en una máscara espantosa, arrostrando la memoria del horror del náufrago? No parece que las palabras del globo de texto tengan nada que ver con esta transformación. Quien habla es Laurie, antigua compañera heroica. Baste saber, por el momento, que Laurie acaba de romper con su novio y ha buscado consuelo en el previsible y hogareño Dan Dreiberg. Ya hemos dicho que Dreiberg, antiguamente conocido como el Búho, héroe enmascarado, es ahora un cuarentón sin aspiraciones. Añadamos que no está en su mejor estado físico y que, por lo que sabemos a las alturas de este capítulo, es un hombre tímido e inseguro, que no quiere meterse en problemas. Tenemos, además, buenos motivos para sospechar que a Dan no le importaría tener una aventura con Laurie, pero de momento no es más que el hombro en que Laurie llora por su ruptura. Es solo el viejo amigo, el viejo compañero de aventuras. El Búho es un traje viejo cubierto de polvo.
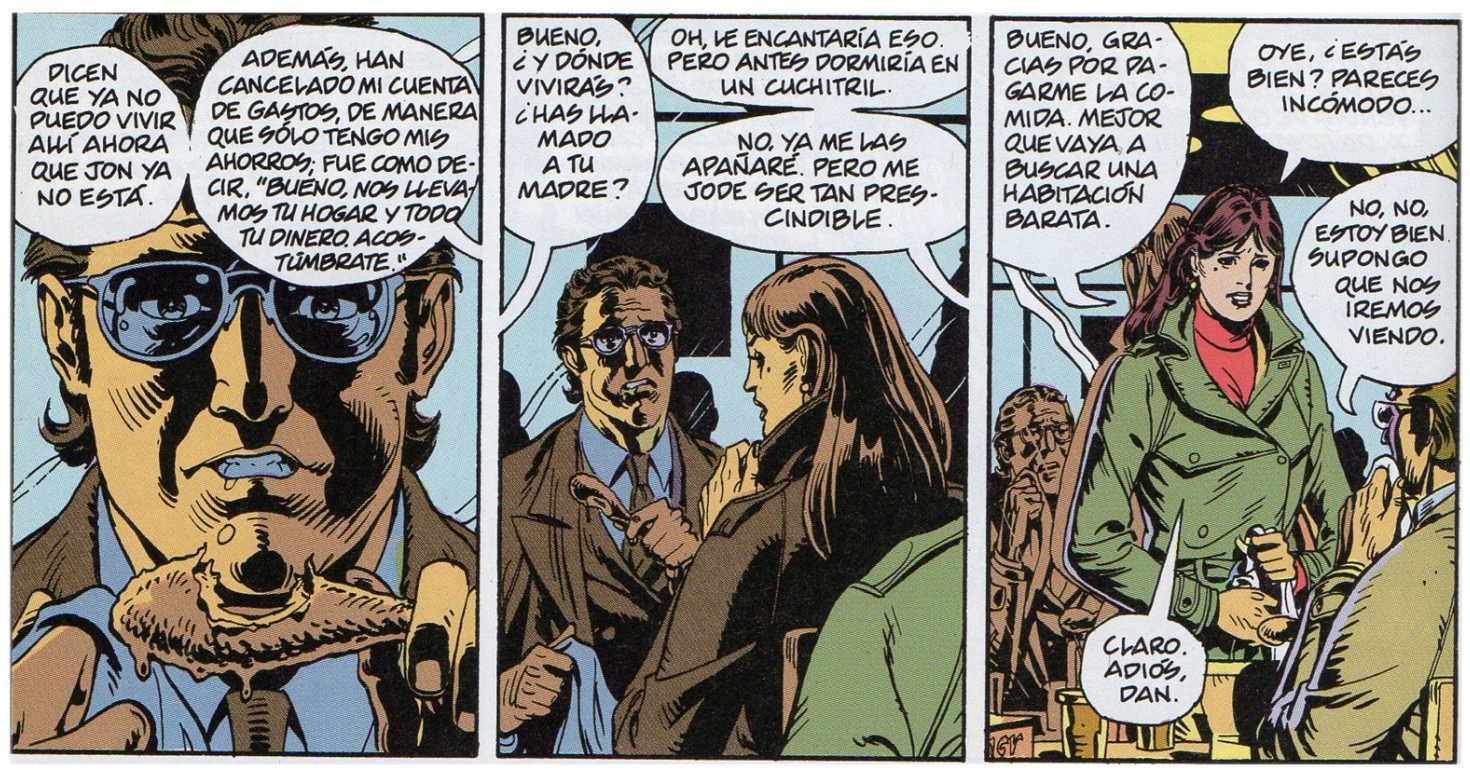

FIG. 10. Watchmen. Alan Moore y Dave Gibbons (1986-87). Cap. vII, p. 10.

\footnotetext{
19 Ricoeur, P. La metáfora viva, Madrid, Trotta, 2001, p. 231.

${ }^{20}$ Acerca de los peligros de asimilar el cine al lenguaje verbal escribió Jean Mitry un brillante ensayo en el que apuntaba que es "más normal comparar las estructuras cinematográficas con las estructuras narrativas que con las del lenguaje." (Mitry, J. La semiología, en tela de juicio. Madrid, Akal, 1990, p. 22). Creo que es una observación pertinente para cualquier forma de arte narrativo.
} 
Algo no encaja en esta historia. ${ }^{21}$ Las sombras del rostro de Dreiberg denotan una pugna en su interior que él, obviamente, desconoce. Alan Moore nos sitúa en una posición de superioridad respecto al personaje: sabemos más de Dreiberg de lo que él mismo sabe. Sabemos que desea a Laurie. Sabemos que le aburre su vida. Sabemos que, de algún modo oscuro, le fascina la perversa rectitud moral de Rorschach, el único héroe que sigue en activo. Sabemos, por ejemplo, que un núcleo reprimido de violencia se asfixia bajo la mascarada rutinaria en la que se ha convertido su vida. Retrocedamos unas cuantas páginas para comprobarlo.
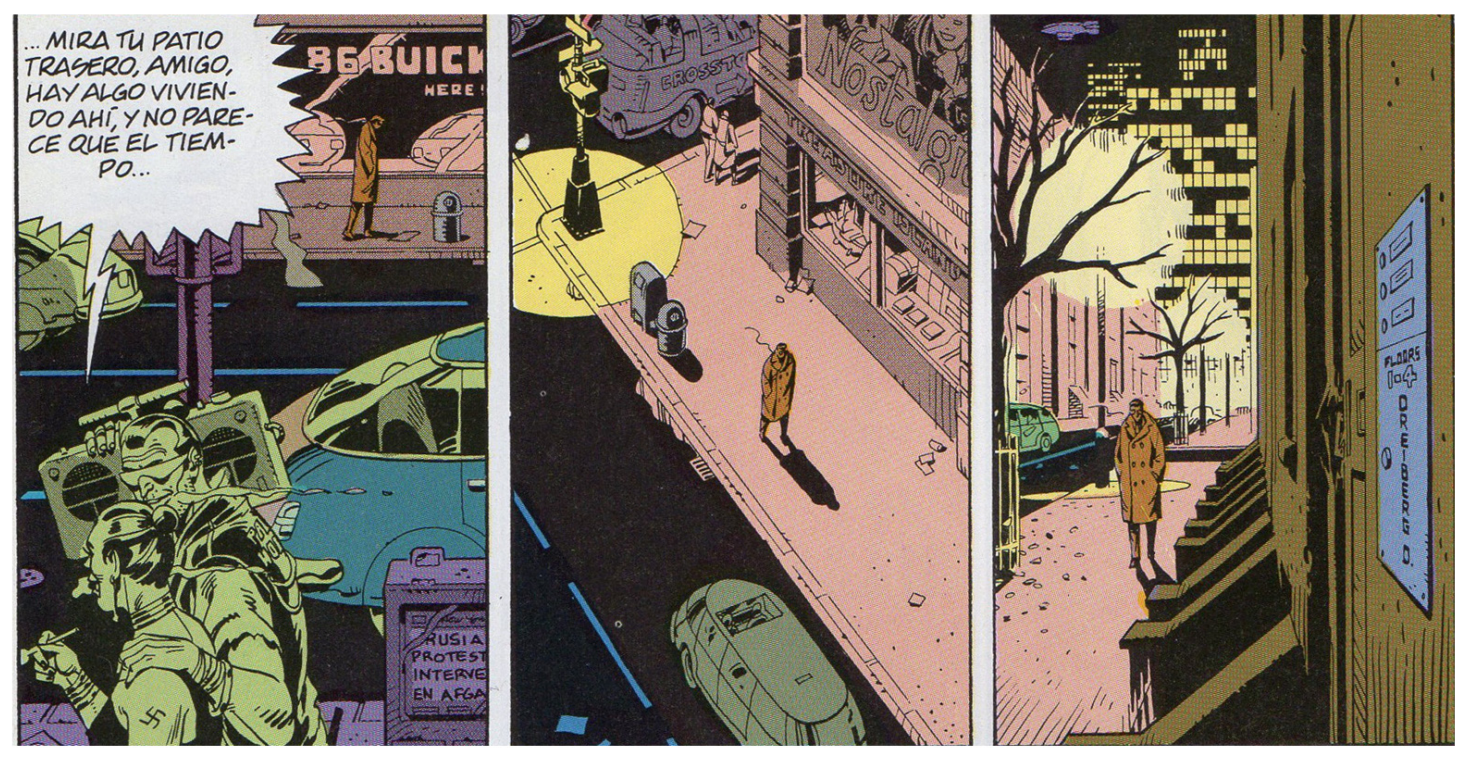

FIG. 11. Watchmen. Alan Moore y Dave Gibbons (1986-87). Cap. I, p. 9.

Regresamos al primer capítulo de Watchmen. Dan Dreiberg vuelve a casa. Como todos los sábados, ha estado tomando unas cervezas con Hollis Mason, el primer Búho Nocturno, ya un anciano. Así pasa Dan los sábados por la noche. Descubrimos en la tercera viñeta que la puerta de su casa está forzada. Un hombre tímido, que pasa los sábados de noche bebiendo cerveza con un anciano, se comportaría como un ciudadano prudente y llamaría a la policía. Ese ciudadano prudente es el Dan que creemos conocer. Cuando acabemos de leer Watchmen seguiremos pensando en el Búho en términos de equilibrio y prudencia pero, en esta escena, en su primerísima aparición, Alan Moore quiere dejarnos claro quién es Dan Dreiberg.

No hay miedo en su mirada. Es furia lo que percibimos. Incluso su contorno se transforma. Las sombras nos muestran al héroe enterrado. Es el Búho quien abre la puerta. Es el Búho a quien vemos avanzar con los puños cerrados.

Diríamos que se dispone a reventar a golpes al intruso.

\footnotetext{
21 El hecho de que la comprensión plena de esta metáfora exija un examen detallado del momento de la trama nos habla de su pertinencia. Si el sentido de un tropo se capta sin el menor esfuerzo es probable que se trate de un giro gastado o de una figura genérica. En palabras de Aristóteles, "Las metáforas (...) hay que obtenerlas de cosas apropiadas, pero no evidentes, igual que en filosofía es propio del sagaz establecer la evidencia”. (Aristóteles. Retórica, Madrid, Editorial Gredos, 1999, p. 534.)
} 


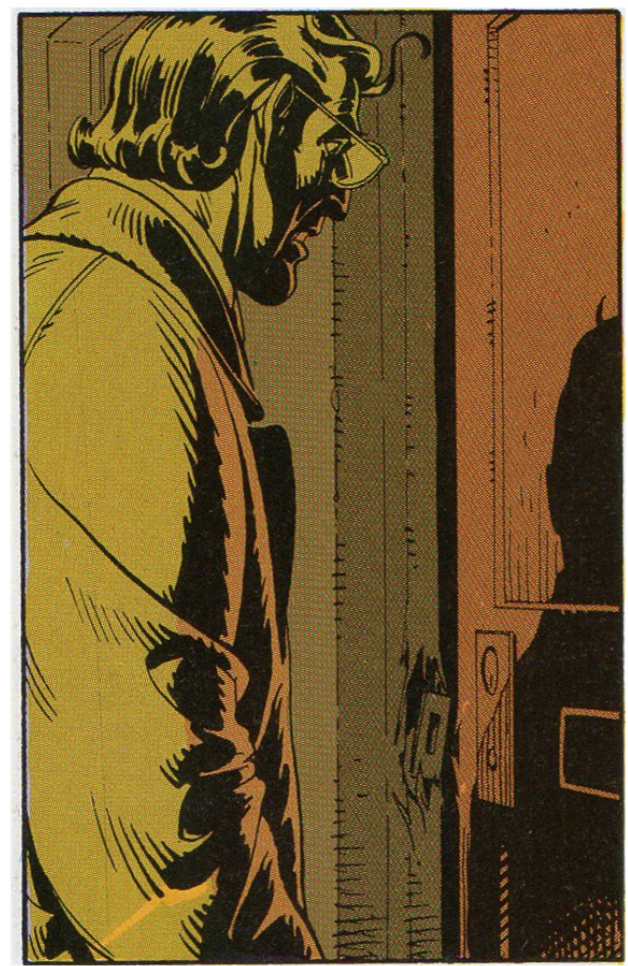

FIG. 12. Watchmen. Alan Moore y Dave Gibbons (1986-87). Cap. I, p. 9.
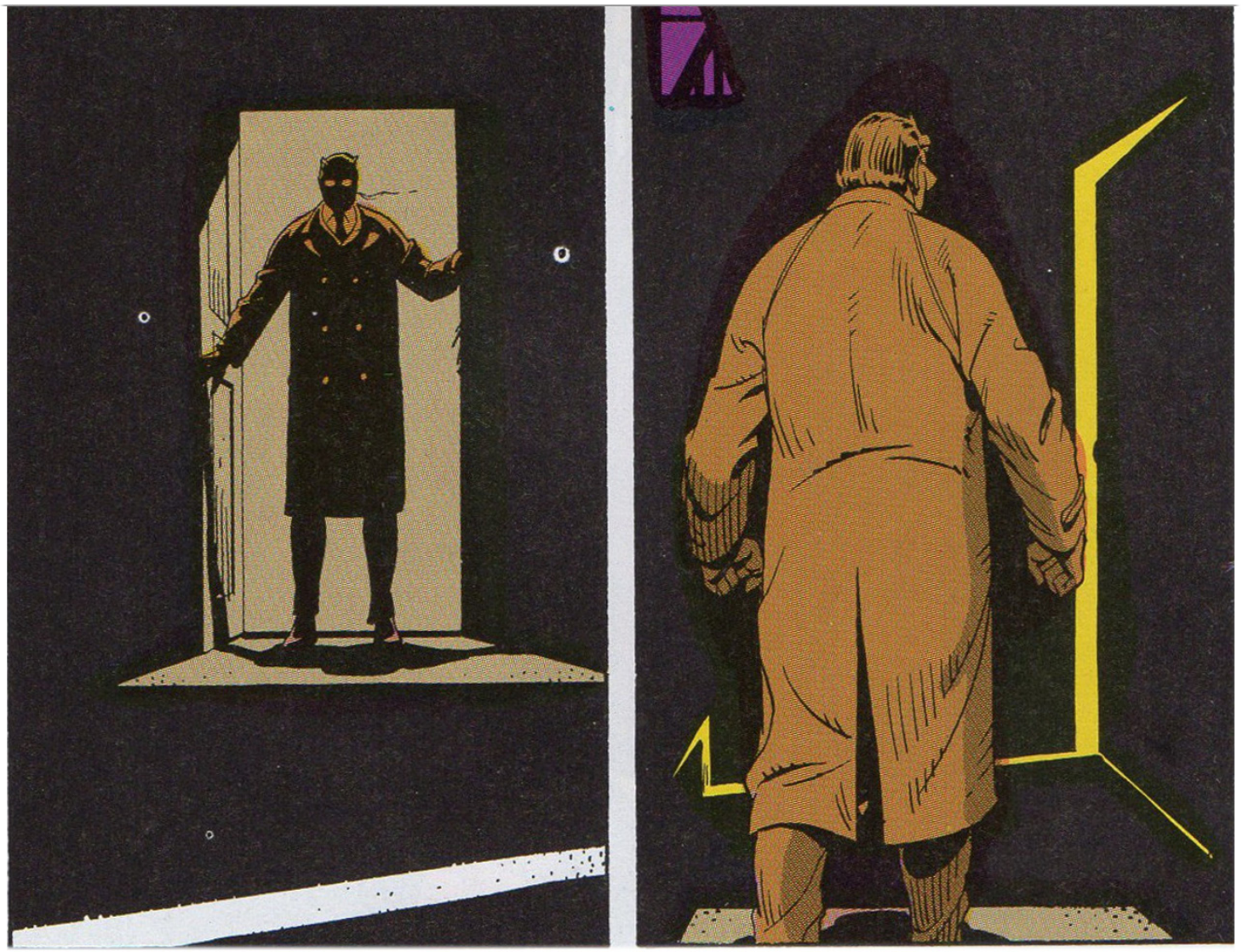

FIG. 13. Watchmen. Alan Moore y Dave Gibbons (1986-87). Cap. I, p. 9. 


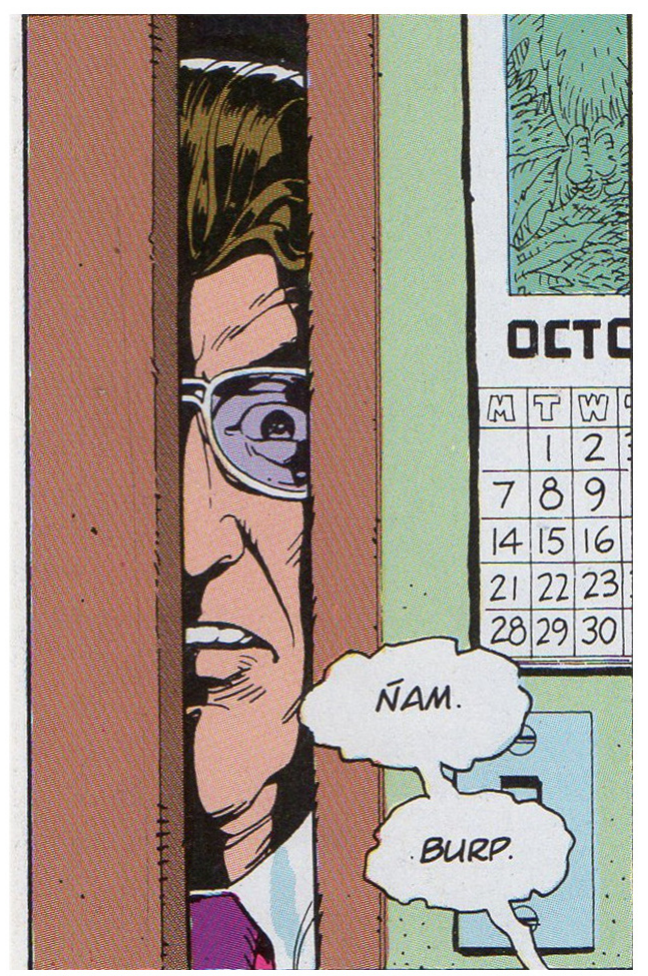

FIG. 14. Watchmen. Alan Moore y Dave Gibbons (1986-87). Cap. I, p. 9.

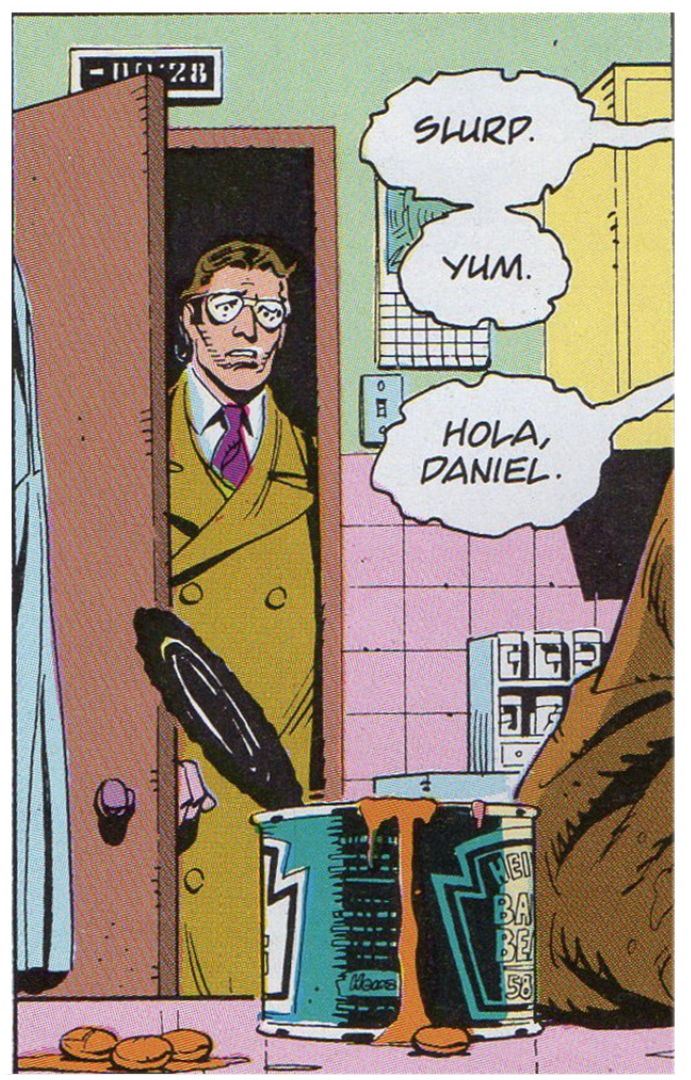

FIG. 15. Watchmen. Alan Moore y Dave Gibbons (1986-87). Cap. I, p. 9. 
Y ahí está el rostro fiero, recorrido por las mismas sombras que, muchas páginas más tarde, el náufrago volverá a proyectar. Alan Moore nos había anticipado la metáfora del quinto capítulo en la escena inicial de Dan. Es la primera vez que vemos claramente la cara de Dan. Se nos aparece fiero, consumido por la rabia, casi enloquecido. Pero recupera el control. En cuanto comprueba que el intruso es su excompañero Rorschach el gesto se relaja y regresa el Dan Dreiberg temeroso y timorato que ocupa la práctica totalidad de las páginas de Watchmen.

El Búho ha dejado paso al ciudadano. De momento. En la dinámica estructural de Watchmen Dreiberg es el héroe educado, tranquilo, reflexivo. El que compensa la naturaleza violenta de otros enmascarados. Y, sin embargo, en su primerísima aparición, Alan Moore nos deja echar un vistazo al fuego que destruye su identidad. Ese mismo fuego es el que resuena en la horrible vivencia que atraviesa el náufrago. En la viñeta que estábamos analizando Dan Dreiberg funciona como un espejo de la subtrama del náufrago y los lectores lo sabemos porque le conocemos mejor que él mismo. Sabemos que necesita al héroe, que su máscara de carne está incompleta sin los ojos del Búho. Así que la metáfora visual que conecta a Dreiberg con el náufrago es mucho más que un mero alarde estético, es un recurso estilístico que subtiende dos momentos de la trama y nos sugiere que el héroe no está muerto. Solo está dormido.

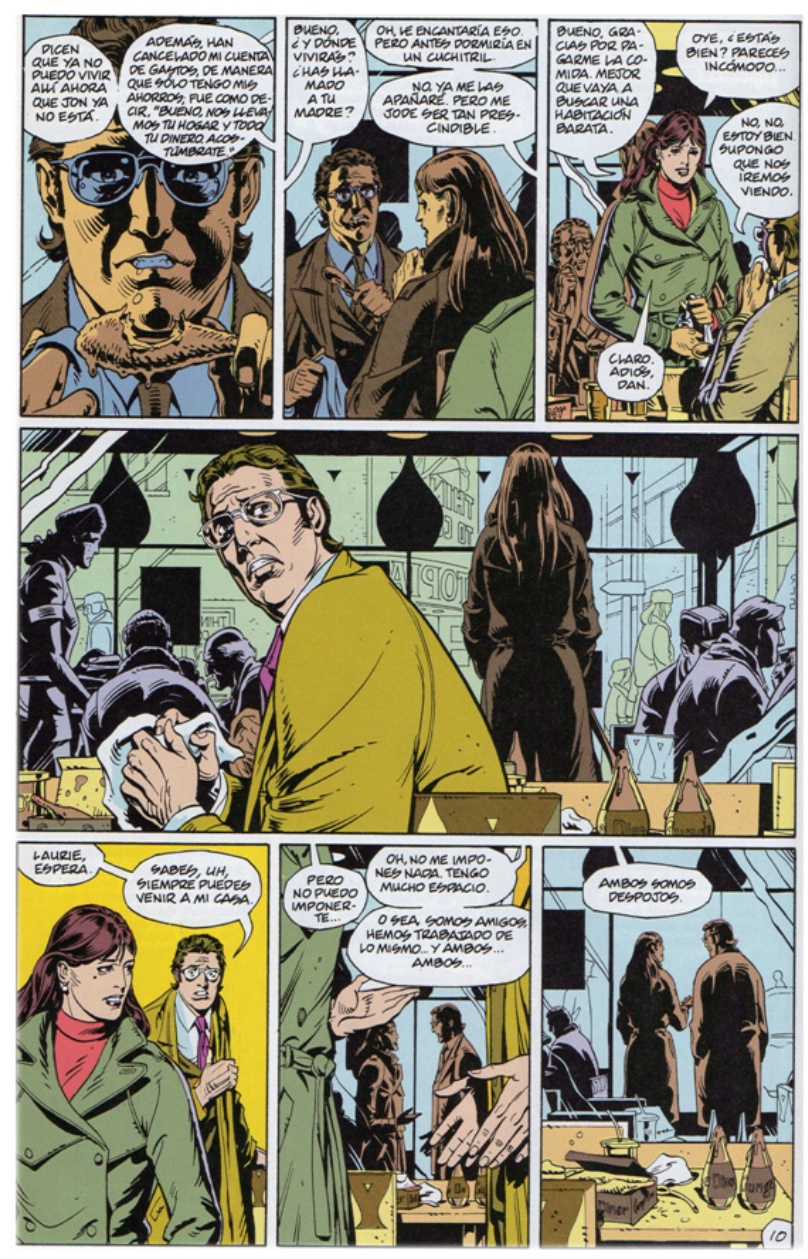

FIG. 16. Watchmen. Alan Moore y Dave Gibbons (1986-87). Cap. vII, p. 10. 
¿Y por qué habría de despertar en este momento? ¿Por qué en la página novena del quinto capítulo Alan Moore nos sugiere que Dan Dreiberg es un reflejo de un náufrago a la deriva? Observemos la página completa.

Laurie le dice a Dan que se va a dormir a una pensión y se despide. Dreiberg entonces le dirige una mirada patética, aterrado ante la perspectiva de perderla, y toma la decisión más importante de su vida. Es un punto clave en la construcción del arco de desarrollo de Dan Dreiberg. En términos de guión puro estamos ante el punto de inflexión que termina con el primer acto de su escaleta. Dan invita a Laurie a dormir en su casa. Lo hace con esa mirada temerosa e insegura que tan bien conocemos, pero lo hace. Algo ha brotado desde el interior de Dan que le he conferido el valor suficiente para iniciar una relación más profunda con la mujer a la que desea.

Nosotros sabemos qué es ese algo. Es el Búho. Es la fuerza que permite a Dan llevarse a la chica y recuperar su identidad enmascarada. Pero antes de que lo logre, en el capítulo siete, Alan Moore le hará sufrir una terrible humillación que comentaremos en la última sección de este artículo. Antes repasaremos algunos recursos estilísticos de Watchmen que nos ayudarán a contextualizar el sistema narrativo de Moore y Gibbons.

\section{NARRADOR, ENCUADRE Y PERSPECTIVA: El valor diacrítico de la viñeta}

Entiendo por valor diacrítico la capacidad intrínseca de la viñeta para modificar la comprensión y / o apreciación lírica del relato. Quisiera aclarar que no estoy sugiriendo la viñeta como "unidad mínima" del cómic. Mi concepto de la viñeta se acerca más a la metáfora de la célula con la que Eisenstein definía los planos: "El plano no es, en modo alguno, un 'elemento' de montaje. El plano es una célula de montaje. Del mismo modo que una célula forma un fenómeno de distinta clase, el organismo o embrión, el montaje se halla al lado opuesto del dialéctico nacer del plano". ${ }^{22}$

Pero, en cualquier caso, los debates acerca de los elementos constitutivos del lenguaje comicográfico me parecen poco pertinentes para el análisis narrativo, por más que resulten fascinantes en términos generales. Más oportunas me resultan las reflexiones en torno a la delimitación de la imagen y a las implicaciones de la perspectiva —o cualquier decisión compositiva - sobre la psique del espectador. Rudolf Arnheim fue uno de los primeros teóricos en explorar en detalle el uso artístico de la delimitación de la imagen en tanto dispositivo narrativo. Cuando encuadramos una imagen, sea formando una cámara con los dedos o filmando una película, estamos restringiéndola: es imposible captar la realidad tal y como la experimentamos. Arnheim considera que sería un error lamentarnos por ello: la selección es, de hecho, la operación que separa lo artístico de lo meramente imitativo.

Creo que esta visión sobre el uso artístico de la delimitación puede resultarnos tan útil para comprender la viñeta como para lo es para comprender la pantalla. Según Arnheim "la delimitación de la imagen es un instrumento tan formativo como la perspectiva, ya que permite destacar y dar particular importancia a determinados detalles, $y$, a la inversa,

${ }^{22}$ Eisenstein, S. M. “El principio cinematográfico y el ideograma”, en Eisenstein, S. M. Teoría y técnica cinematográficas. Madrid, RIALP, 2002, p. 92. 
permite omitir cosas sin importancia, introducir sorpresas visuales repentinamente, presentar reflejos de cosas que están ocurriendo 'afuera'."23

Así entendida, la delimitación nos remite a las decisiones estéticas del narrador. Ya hemos visto cómo Alan Moore abre el plano para mostrarnos la escena sexual que traumatiza al joven Rorschach pero lo cierra, con pudor, en el caso del trauma infantil de Laurie. El narrador restringe la información para ajustarse a las necesidades de lo narrado. A veces corresponde apartar la mirada.

Dice Nöel Burch, refiriéndose a un pasaje de una obra de Renoir, que "es sobre todo el campo vacío lo que atrae la atención sobre lo que sucede fuera de campo (y por tanto en

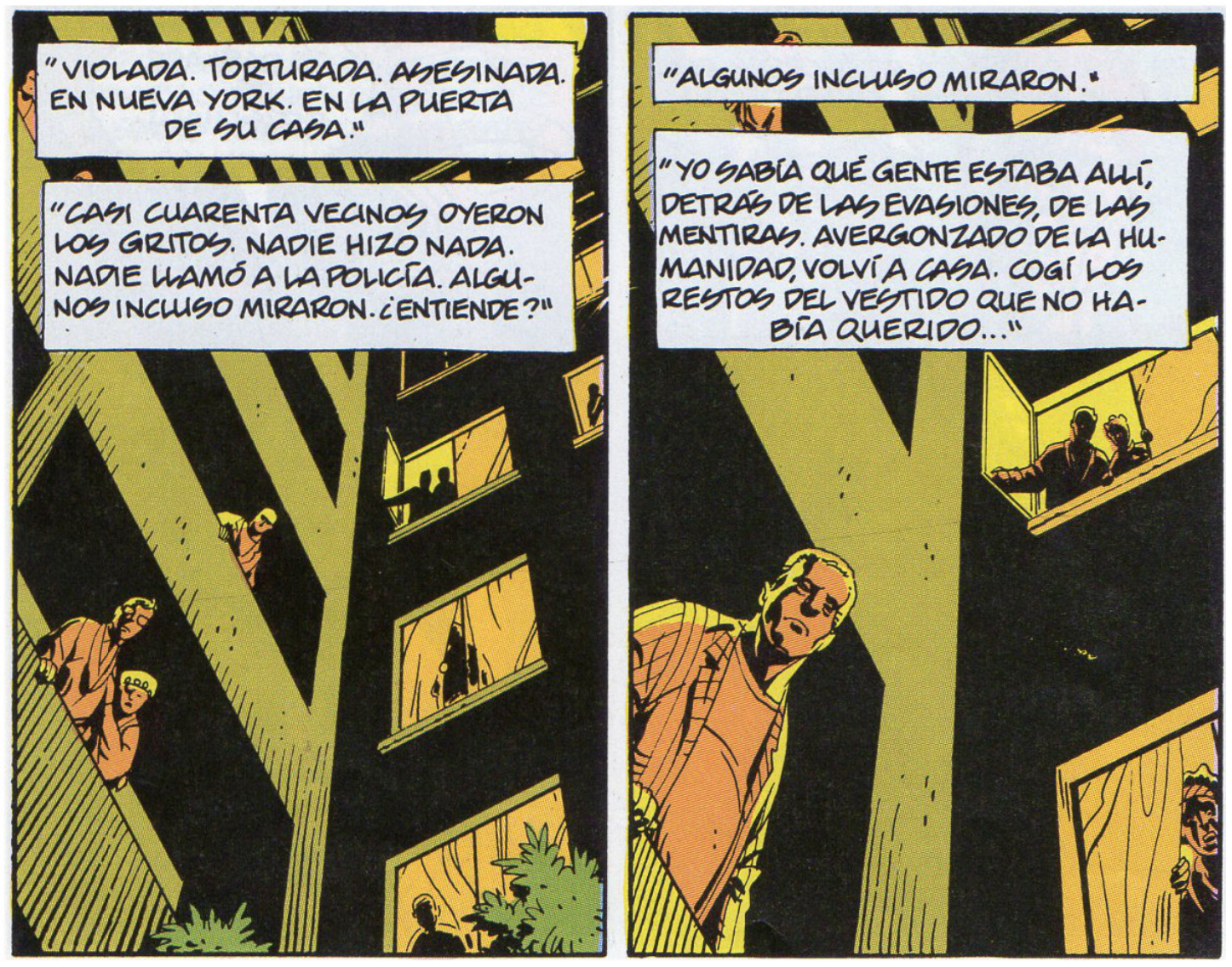

FIG. 17. Watchmen. Alan Moore y Dave Gibbons (1986-87). Cap. vI, p. 10.

el espacio-fuera-de-campo) puesto que nada, en principio, retiene ya (o todavía) la vista en el campo propiamente dicho". ${ }^{4}$ Podemos afirmar, por cierto, que la presencia física del texto en estas dos viñetas impulsa el efecto del campo vacío y convierte la violación elidida en un espectáculo si cabe más terrible.

Demos un paso más allá. No hace falta mover la cámara, ni siquiera montar los fotogramas, para producir efectos psicológicos en el espectador. Según Balázs la angulación de la

\footnotetext{
23 Arnheim, R. El cine como arte. Paidós Ibérica, 1986, p. 59.

${ }^{24}$ Burch, N. Praxis del cine. Madrid, Editorial Fundamentos, 2003, p. 28.
} 
cámara "es el más fuerte de los medios de caracterización que el film posee; y no se trata de reproducción sino de producción genuina". ${ }^{25}$ Añado que tampoco es necesario en el cómic recurrir al aparato gráfico para lograr alterar u orientar la percepción del lector. La perspectiva y la angulación tienen valor diacrítico en cualquier arte visual. El efecto psicológico de la perspectiva no puede desligarse del resto de elementos que componen el plano. El escritor de cómics puede utilizar la delimitación y composición de la viñeta para producir efectos que amplíen la resonancia de su relato hasta conducirlo, sutilmente, hacia nuevos significados.

Veamos dos ejemplos de planos picados en los que la sinergia que se crea entre la perspectiva, el momento de la trama y el subtexto provoca efectos narrativos completamente diferentes.

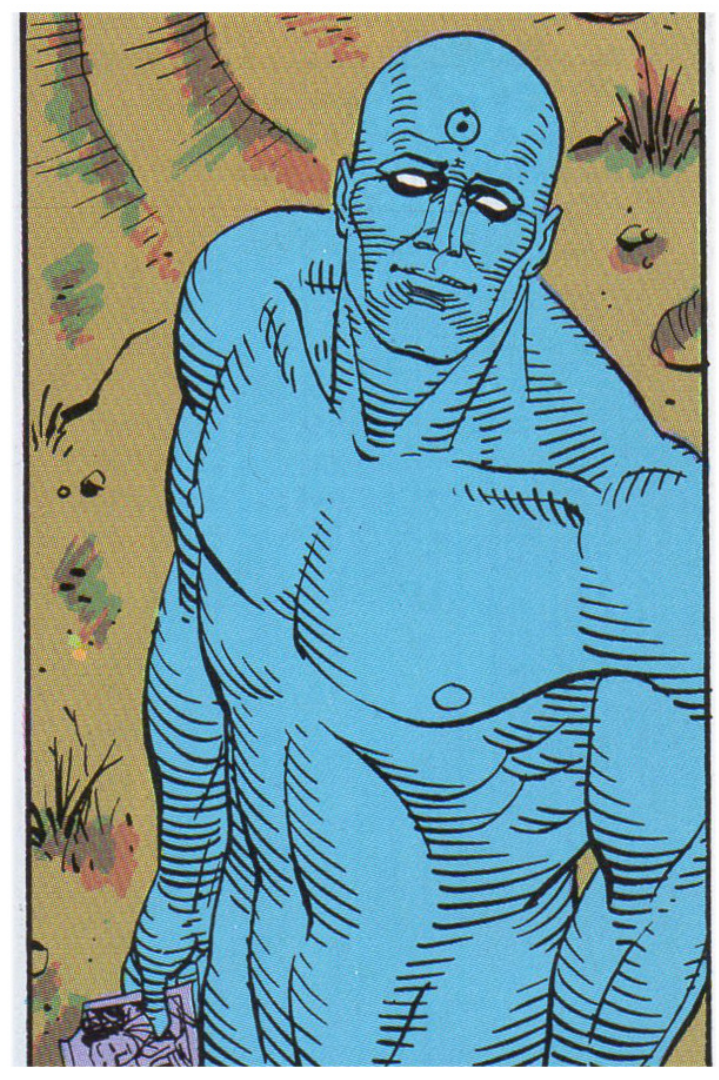

FIG. 18. Watchmen. Alan Moore y Dave Gibbons (1986-87). Cap. III, p. 21.

Jon, el Dr. Manhattan, está mirando las estrellas. Su novia acaba de abandonarle, quebrando así sus tenues lazos con la especie humana. En la mano lleva una foto de Janey Slater, su primera novia, a la que conoció cuando aún era un simple humano. Sospechamos que está a punto de abandonar la tierra. Parece feliz. El picado en primer plano nos sugiere algo más; el gesto podría denotar humildad frente a la inmensidad del espacio. O quizá se trate de alivio ante la perspectiva de dirigirse hacia una forma de vida más sencilla y gratificante. En cualquier caso, el plano picado contribuye a afianzar la ironía dramática que da cuerpo a toda la escena. En el preciso instante en el que el Dr. Man-

${ }_{25}$ BALÁzs, B. Theory of the Film: character and growth of a new art. Londres Dennis Dobson Limited, 1952, p. 47. 
hattan se dispone a romper sus lazos con la humanidad, sonríe. Es un ser semidivino, el superhombre de Nietzsche, que se dispone a viajar a Marte pero lleva consigo una vieja foto de una mujer a la que ya no ama. La sonrisa es, acaso, un recordatorio de que el Dr. Manhattan es un hombre cansado, no un dios impasible. El plano picado contribuye a enfatizar esta modestia rebajando levemente su figura y amplificando el efecto tranquilizador de su sonrisa.

Veamos el segundo ejemplo.

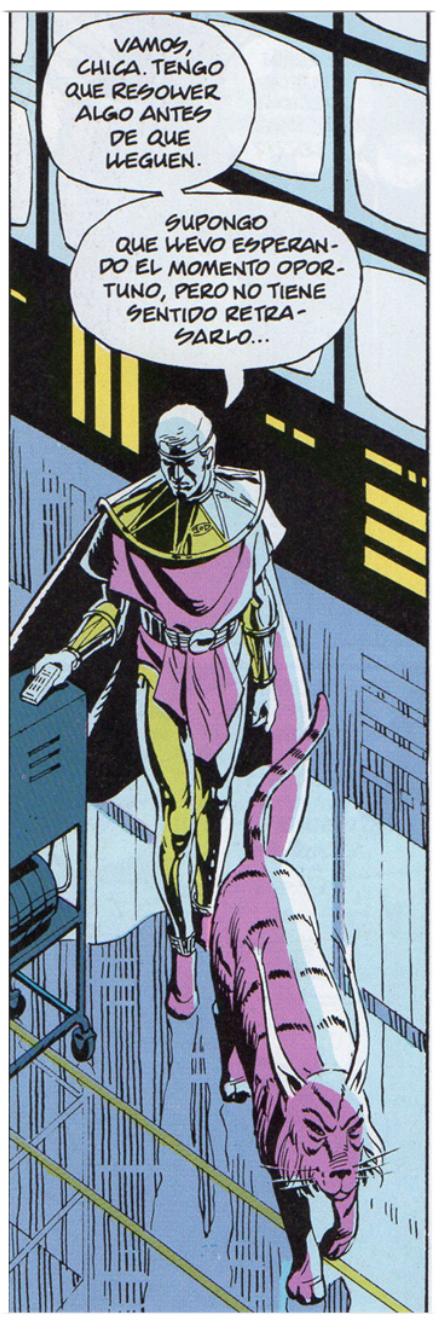

FIG. 19. Watchmen. Alan Moore y Dave Gibbons (1986-87). Cap. XI, p. 4.

De nuevo un plano picado, aunque más abierto y elevado. Adrian Veidt (Ozymandias) y Bubastis se preparan para luchar contra Rorschach y el Búho, aunque Veidt debe resolver antes algunos asuntos. Entre ellos, preparar la secuencia que conducirá a la muerte de cinco millones de seres humanos. Se puede considerar que Veidt es un monstruo pero más adelante sabremos que no es insensible al dolor ajeno. Ha tomado la decisión final y está dispuesto a cargar con el peso de los muertos sobre sus hombros. Queda claro, entonces, que un plano contrapicado sería contraproducente, puesto que contribuiría a crear un efecto de engrandecimiento heroico que Veidt está lejos de sentir. Cualquier enfoque a la altura de los ojos sería menos potente que la vista seleccionada, porque normalizaría una 
subtrama emocional que resulta extrema. La perspectiva elegida por Moore y Gibbons, y esa diagonal descendente tan marcada, sitúan el peso de la composición sobre Veidt. E1 orden de la marcha y el gesto, entre sombrío y resignado, nos sugieren que Ozymandias es, en este momento, un general a punto de ordenar una maniobra suicida que acabará con muchas vidas para que otros puedan seguir adelante. La siguiente viñeta confirma la sensación.

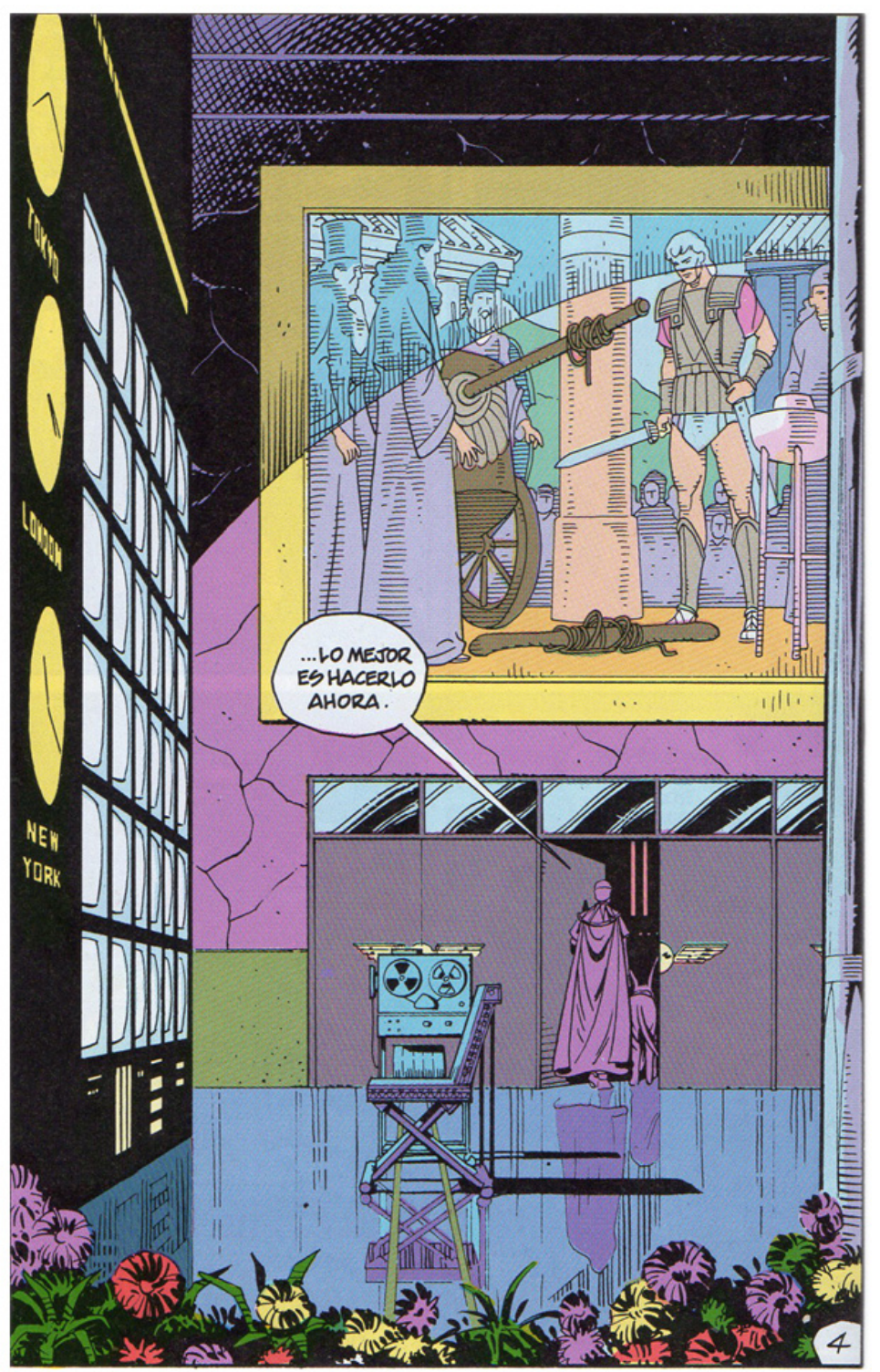

FIG. 20. Watchmen. Alan Moore y Dave Gibbons (1986-87). Cap. XI, p. 4.

Queda claro que el plano picado de la viñeta anterior contribuía a enfatizar la identificación entre Alejandro Magno y Ozymandias, la idea del general que se atreve a romper el nudo gordiano, a llegar más allá de lo que nadie había soñado nunca. Pero el momento no es feliz porque no hay vuelta atrás y cruzar el Rubicón implica cargar con el peso de cinco millones de muertos. De todos modos, aún deberíamos aclarar por qué Bubastis ocupa un lugar tan importante en el picado. La explicación nos la da la siguiente página, el momento en el que Adrian Veidt activa la secuencia que inundará de sangre las calles de Nueva York. 

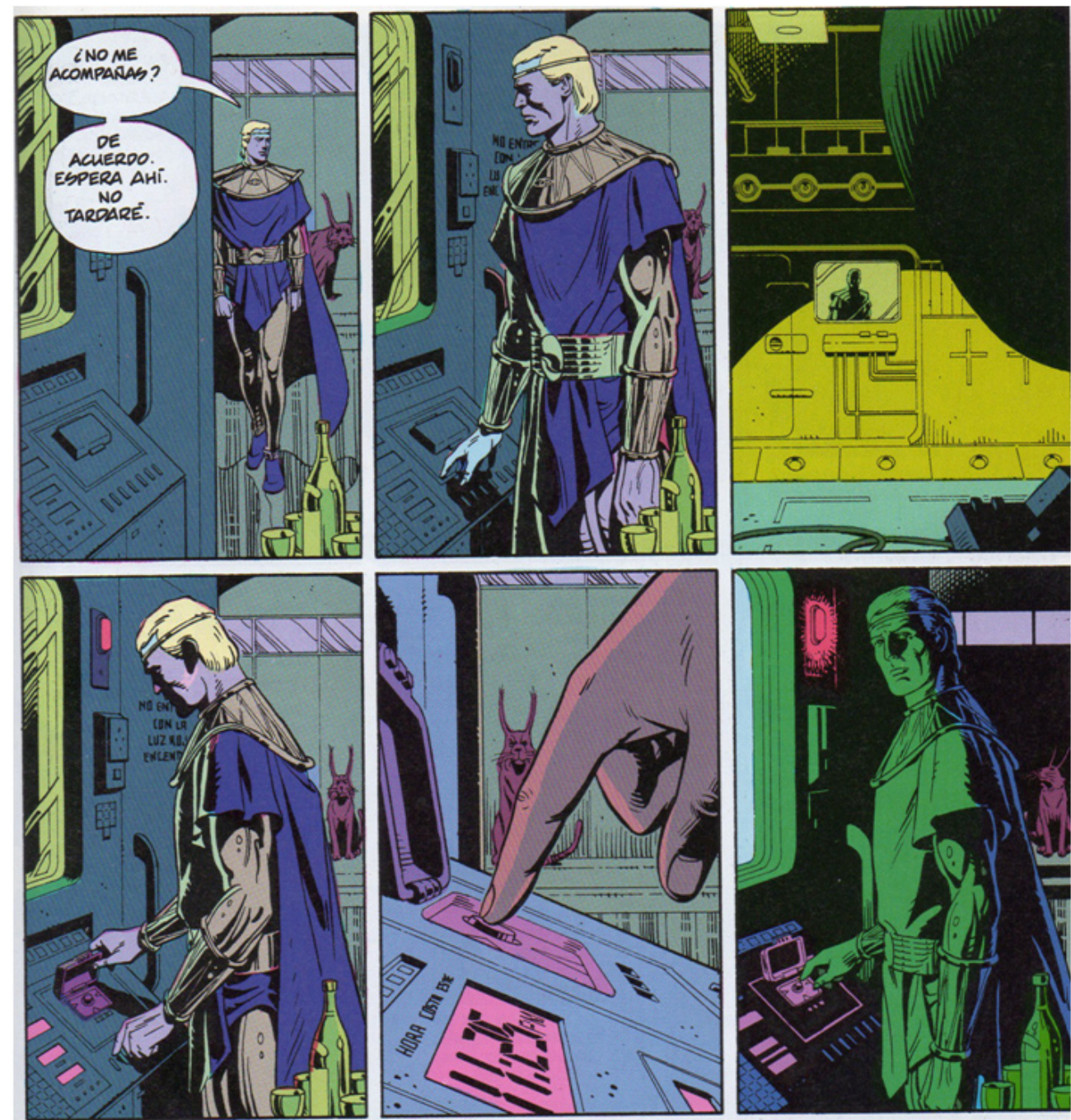

FIG. 21. Watchmen. Alan Moore y Dave Gibbons (1986-87). Cap. XI, p. 5.

Bubastis se queda a la puerta porque Veidt debe tomar la decisión solo. No habrá cómplices de su matanza, nadie con quien compartir la culpa. Bubastis es el único testigo del asesinato de Veidt. No puede comprender lo que sucede, no puede juzgarle, pero desnuda la conciencia de Ozymandias más de lo que pueden las palabras. Es el testigo mudo que permite a Alan Moore introducirse en la conciencia de Veidt mediante el lenguaje indirecto. ¿Qué está pensando el tigre? Nada. Simplemente espera. Pero Moore nos sugiere que Veidt se sabe observado por la posteridad. Los ojos de Bubastis son su conciencia silenciada. Va a asesinar a cinco millones de personas. No podrá conocer jamás el descanso. La perspectiva en picado dibujó al general que acepta su destino. El encuadre sobre los ojos de la tigresa habla de su imperdonable decisión. Esta escena es, desde mi punto de vista, un estupendo testimonio del valor diacrítico intrínseco a la viñeta, que trasciende, con mucho, el rol decisivo atribuido a la secuencialidad.

\section{MonTAJE Y SISTEMA NARRATIVO: El poder del nueve}

La investigación sobre las estrategias de lectura y el recorrido visual es uno de los ámbitos de la teoría del cómic que más pueden interesar para desarrollar un modelo de 
análisis narrativo. A este respecto toda la obra de Neil Cohn es, por extensión y calidad, referente obligado. ${ }^{26}$ Creo que sería provechoso para el progreso del medio implementar los trabajos sobre cognición visual con un examen detallado de las formas en las que el montaje permite desgranar la trama. Las características intrínsecas de las diversas rejillas a disposición del narrador facilitan o desalientan, de por sí, determinadas configuraciones expositivas. La cuestión permanece, hasta donde yo conozco, poco tratada. Watchmen puede aportarnos algún fundamento sólido para examinar la relación entre página, montaje y narración puesto que Alan Moore ${ }^{27}$ exprime sistemáticamente las posibilidades que
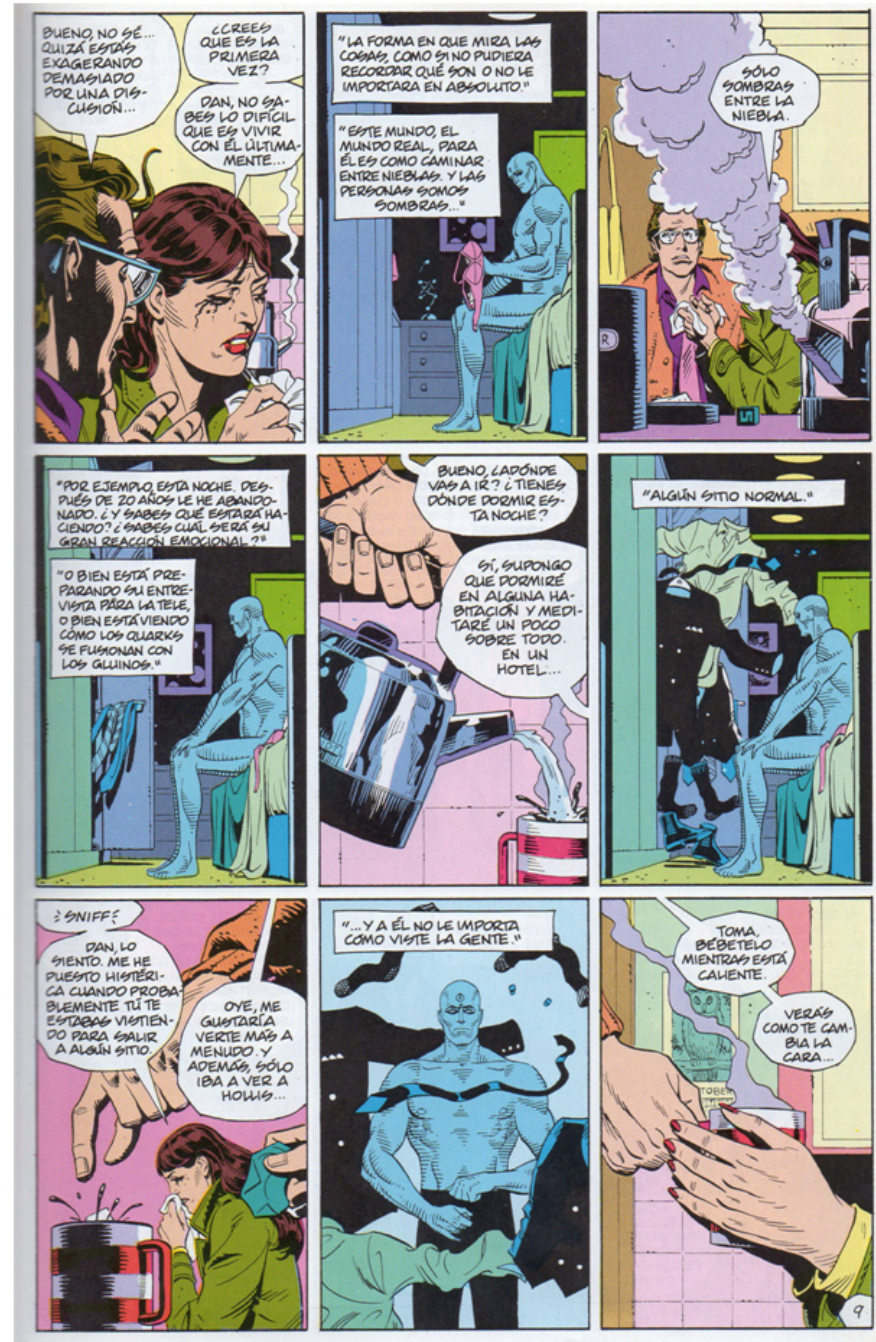

FIG. 22. Watchmen. Alan Moore y Dave Gibbons (1986-87). Cap. III, p. 9.

\footnotetext{
${ }^{26}$ En especial Cohn, N. "Navigating comics: an empirical and theoretical approach to strategies of reading comic page layouts" en Front. Psychol. 4:186 (2013), disponible on line en http://journal.frontiersin. org/Journal/10.3389/fpsyg.2013.00186/full

${ }^{27}$ En este punto conviene destacar una de tantas aportaciones fundamentales de Dave Gibbons a la estructura narrativa de Watchmen. Como desvela el propio Gibbons en una entrevista publicada por la web Con $C$ de Arte (Pérez, P. "No me gusta llamar la atención demasiado sobre el dibujo" en Con C de Arte, 18 de Octubre de 2007, http://concdearte.blogspot.com.es/2007/10/prefiero-no-llamar-demasiado-laatencin.html), fue él quien aconsejó utilizar una rejilla de nueve viñetas. Asumiré igualmente que todas las decisiones narrativas corresponden a Moore para mantener el énfasis en el análisis de la escritura pero este es un buen momento para insistir en que la forma de contar un cómic depende tanto del dibujante como del guionista. No es fácil precisar el ámbito de influencia de los autores.
} 


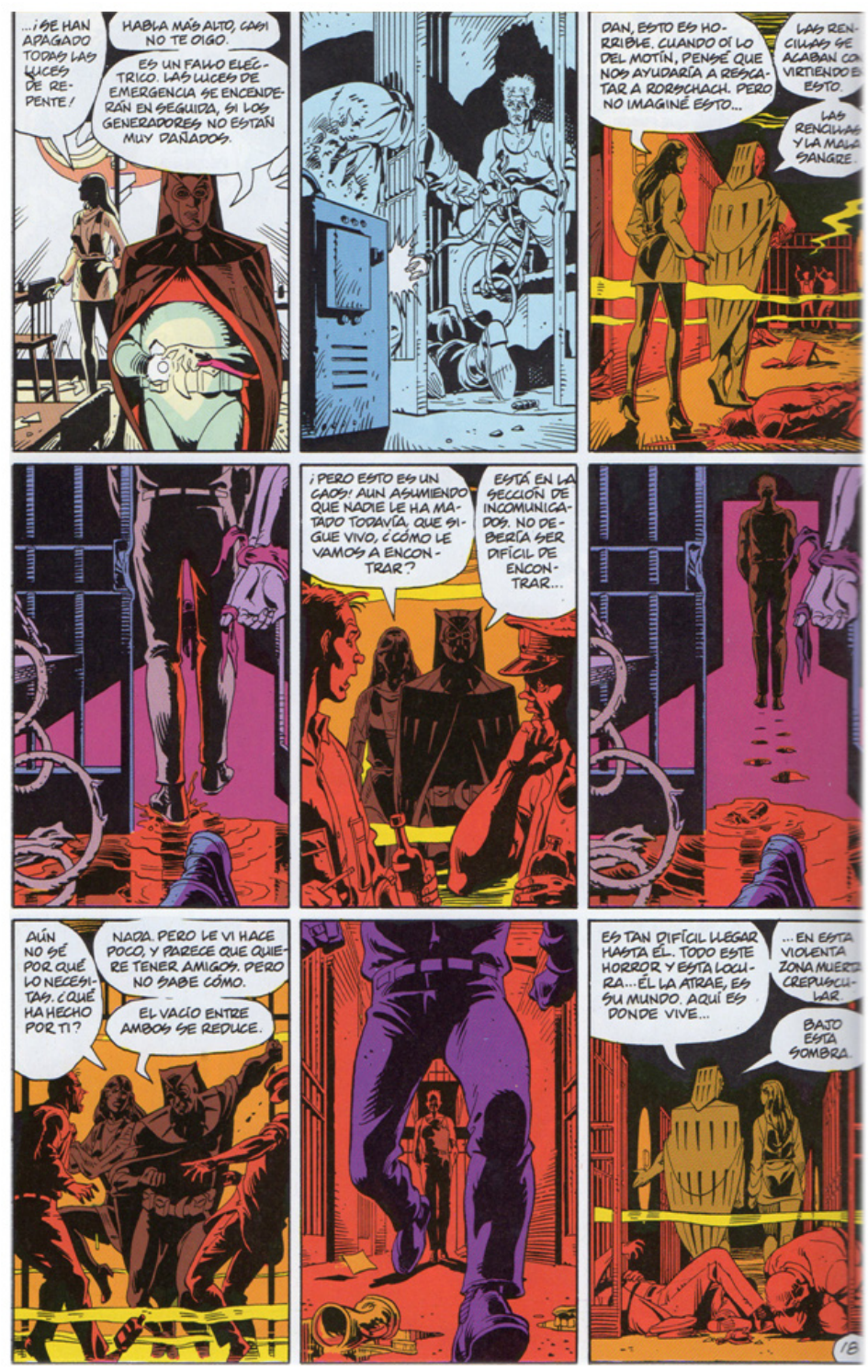

FIG. 23. Watchmen. Alan Moore y Dave Gibbons (1986-87). Cap. viII, p. 18.

le ofrece la rejilla de nueve a partir de un descubrimiento que no tiene nada de trivial: el nueve es un número impar.

Al ser impar el número de viñetas y regular la forma de la rejilla, las viñetas pares forman un rombo $(2,4,6$ y 8$)$ en el que se coloca la trama secundaria. La trama principal utiliza las viñetas impares, reforzando así visualmente su importancia. No solo dispone de una viñeta más que la trama secundaria sino que ocupa la central y, por tanto, las diagonales. De esta manera, la estructura contribuye a distinguir, cuantitativa y cualitativamente, entre ambas tramas. Podríamos denominar a esta distribución "montaje en rombo".

Es característico de Alan Moore que la acción secundaria sirva como resonancia metafórica de la principal. En el pulso principal de esta página Laurie se confiesa ante Dan Dreiberg y en la acción secundaria, que "recibe" la carga simbólica del texto de la principal, el Dr. Manhattan se prepara para ir a una entrevista. Mientras Laurie afirma que al Dr. Manhattan no le preocupan las acciones humanas vemos en el rombo actitudes 
por parte de este que nos hacen dudar. En un cómic como Watchmen, que descansa en la narración paralela y en el montaje de atracciones entre texto e imágenes, un sistema narrativo como este resulta especialmente poderoso.

Este dispositivo sirve, además, para crear ritmo, una de las grandes preocupaciones de Alan Moore. La estructura funciona como bordón y establece en el receptor una dinámica de lectura que le hace asumir de antemano que la trama desgranada en las viñetas pares será la secundaria y la metafórica, mientras que la principal se situará en las viñetas impares. Al formar parte la viñeta central de las impares, se asegura visualmente la primacía estructural de la trama sobre la subtrama. Alan Moore no utiliza siempre el sistema del rombo para narrar acciones paralelas, aunque recurre a él a menudo.

A estas alturas deberíamos haber aprendido ya a desconfiar de las intenciones de Moore tanto como a confiar en su pericia. Este sistema narrativo también se presta a la manipulación de la voz autorial para reflejar la evolución emocional de los personajes. Me gustaría concluir este artículo comentando brevemente uno de los ejemplos de adecuación entre consciencia y narración más impresionantes de los que yo haya visto en el mundo de la narración gráfica. Cuesta imaginar un uso más inteligente de la estructura. Y también uno más perverso.

Estamos en el capítulo siete, "Hermano de Dragones". Ya sabemos que Dan Dreiberg necesita al Búho tanto como necesita a Laurie. Si no los consigue, quizá le devore su furia interior. El Búho es aún un traje polvoriento pero la relación con Laurie avanza. Aunque

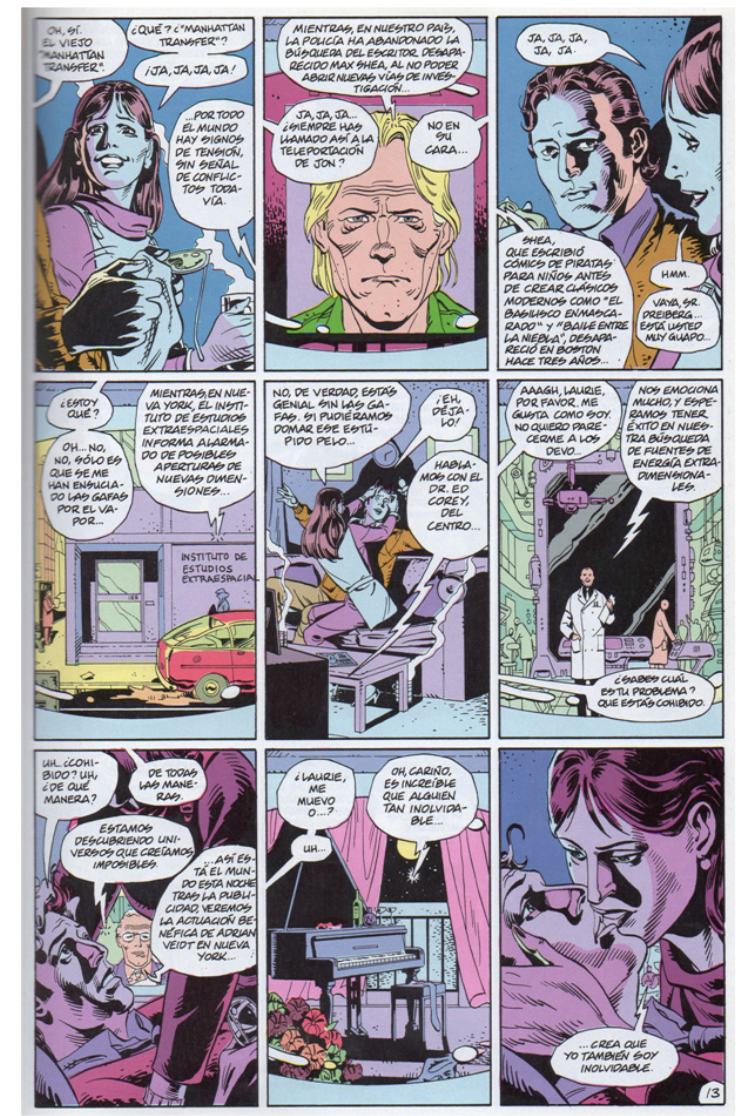

FIG. 24. Watchmen. Alan Moore y Dave Gibbons (1986-87). Cap. vII, p. 12. 
aún no ha habido aproximación sexual, el capítulo siete está lleno de insinuaciones eróticas o afectivas más o menos casuales que van afianzando en la mente del lector la idea de que habrá sexo entre Dan y Laurie. En la página 12 Laurie y Dan aún están viendo el telediario, así que Moore coloca las imágenes del telediario en las viñetas impares (trama principal) y a Dan y Laurie en el rombo (trama secundaria). Pero en cuanto comienza el acercamiento sexual, en la página 13 , se invierte la posición de la trama y la subtrama. Laurie y Dan disfrutan de la viñeta central y de las diagonales. Al menos de eso sí que pueden disfrutar.

La voz del telediario comienza a relacionar trama y subtrama a partir de la octava viñeta. Por fin Dan Dreiberg toma el control de su vida. La sombra del náufrago que vimos en su cara, su violencia reprimida, el fuego que amenazaba con consumirle empieza, por fin, a disiparse. Al final de este capítulo Dreiberg recuperará la confianza en sí mismo, volverá a vestir la máscara del Búho y se llevará a la chica. Es el arco clásico de Hollywood: el chico necesita algo que no se atreve a confesar; el chico conoce a la chica; la relación le da el valor que necesita para cumplir sus sueños. Al final lo consigue todo. Dan Dreiberg creía ser un héroe felizmente retirado pero, al conocer a Laurie, recupera la confianza en

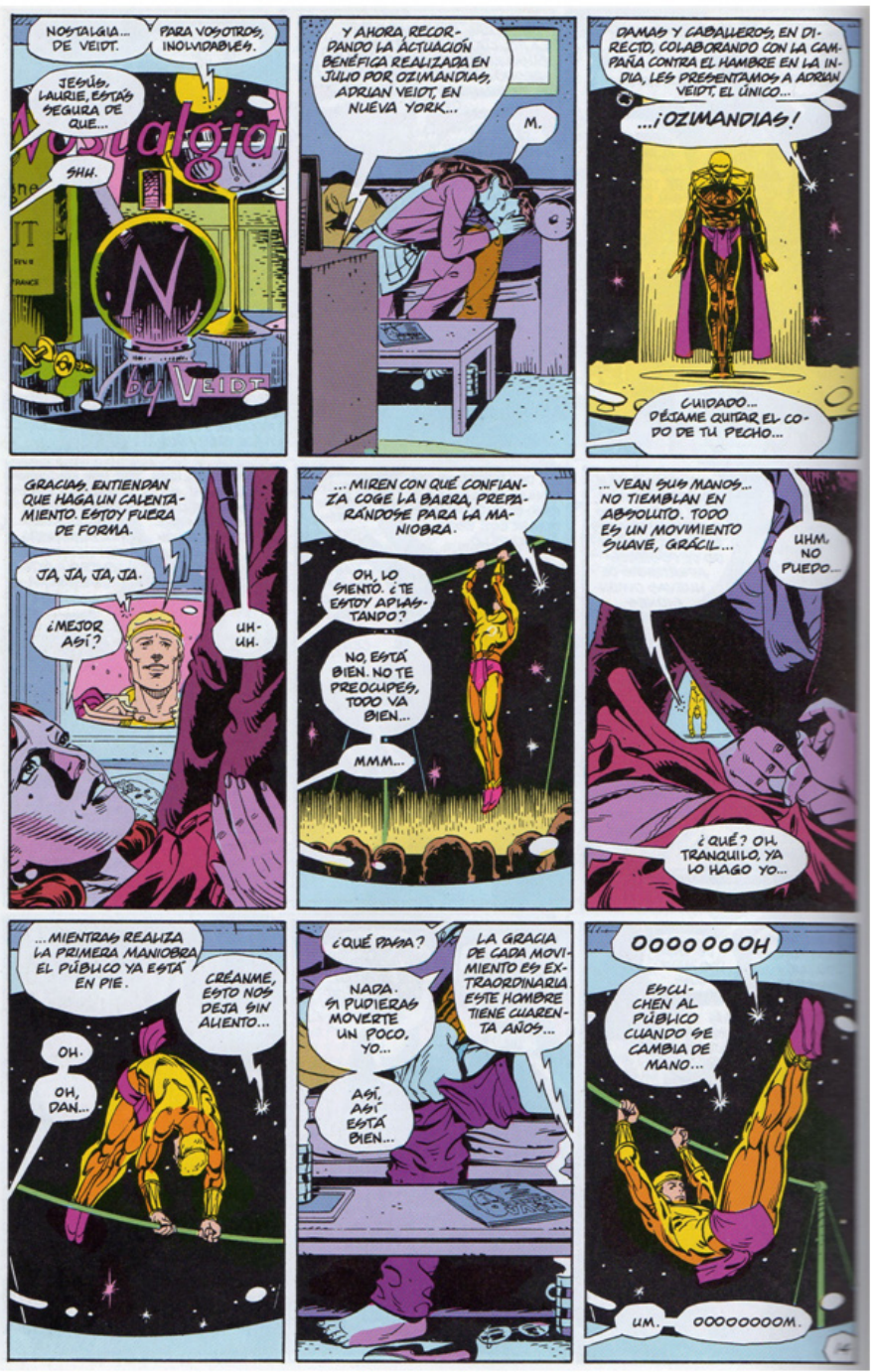

FIG. 25. Watchmen. Alan Moore y Dave Gibbons (1986-87). Cap. VII, p. 13. 
sí mismo y cumple su oscuro deseo: vuelve a ser un superhéroe. Y se queda con la chica. Fin de la historia. Fundido a negro.

Pero esto no es Hollywood. Dan se lleva todos los premios, sí, pero Alan Moore le hará sufrir tres humillaciones antes de concedérselos.

La primera humillación es la más obvia: la física. Primero contemplamos su torpeza. Luego, su impotencia. La segunda humillación es mucho más cruel. La televisión, en montaje paralelo, muestra escenas de un pletórico Ozymandias que, pese a tener la misma edad que Dan, ejecuta acrobacias que contrastan con la azorada escena que se desarrolla en el sillón. La tercera humillación es estructural. Alan Moore ajusta la narración para que amplifique el fracaso de Dan Dreiberg. Si nos fijamos de nuevo en la página, las proezas de Ozymandias pasan a ocupar las viñetas impares y el intento sexual, que había comenzado como la acción central en la página 13, se ve relegada al rombo. Moore nos está diciendo, a través de la estructura, que Dreiberg es la trama secundaria, que no puede

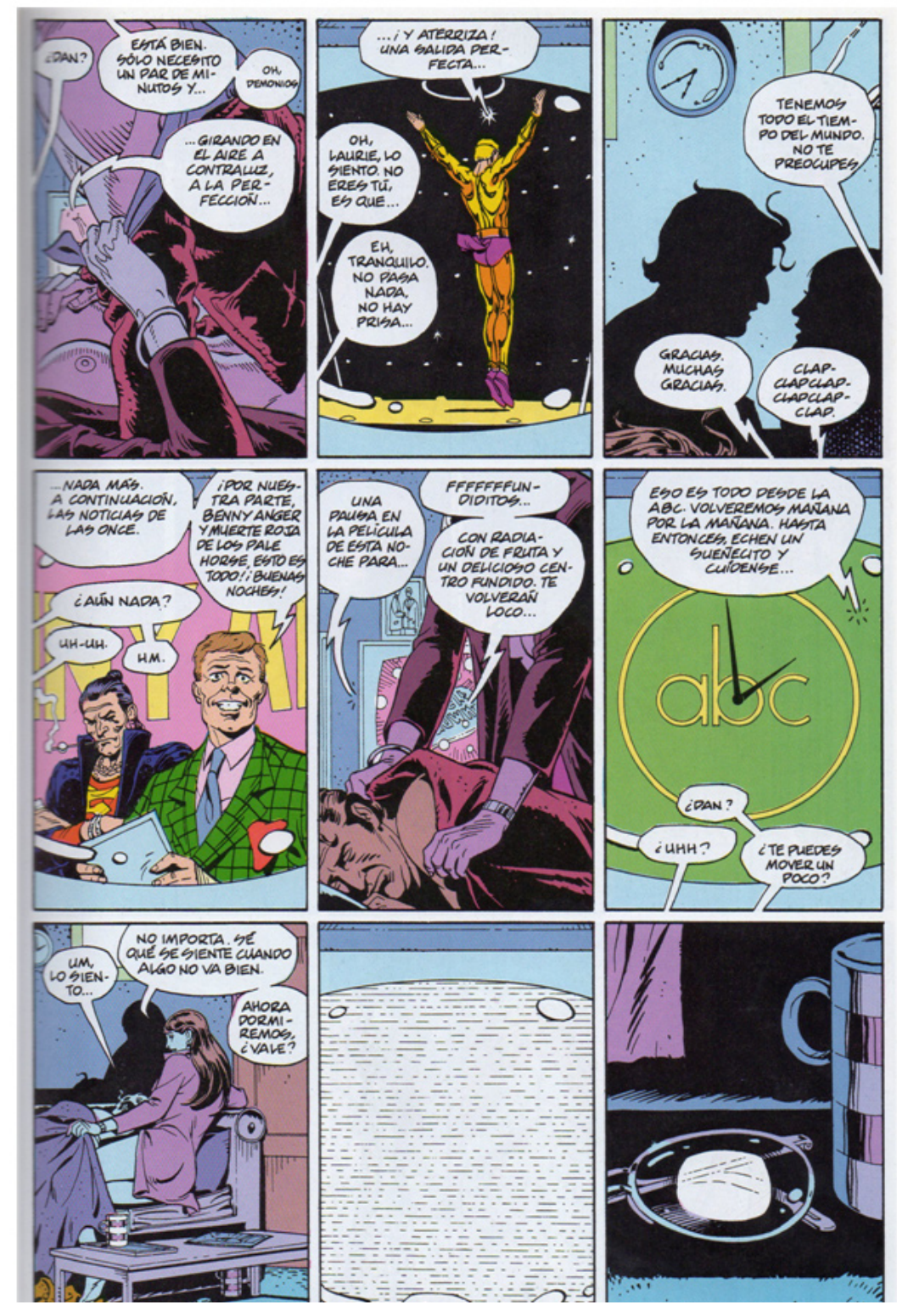

FIG. 26. Watchmen. Alan Moore y Dave Gibbons (1986-87). Cap. viI, p. 14. 
competir con Ozymandias ni siquiera por el espacio visual. Más aún, los diálogos de Laurie y Jon son metáforas cómicas de la voz televisiva. "Créanme, esto nos deja sin aliento". En la siguiente página Ozymandias aterriza logrando "una salida perfecta" mientras que Laurie consuela a Dan y le arropa como si fuera un niño. La estructura recupera su dinámica habitual. La televisión regresa al rombo de las viñetas pares y la trama recupera su puesto en las viñetas impares.

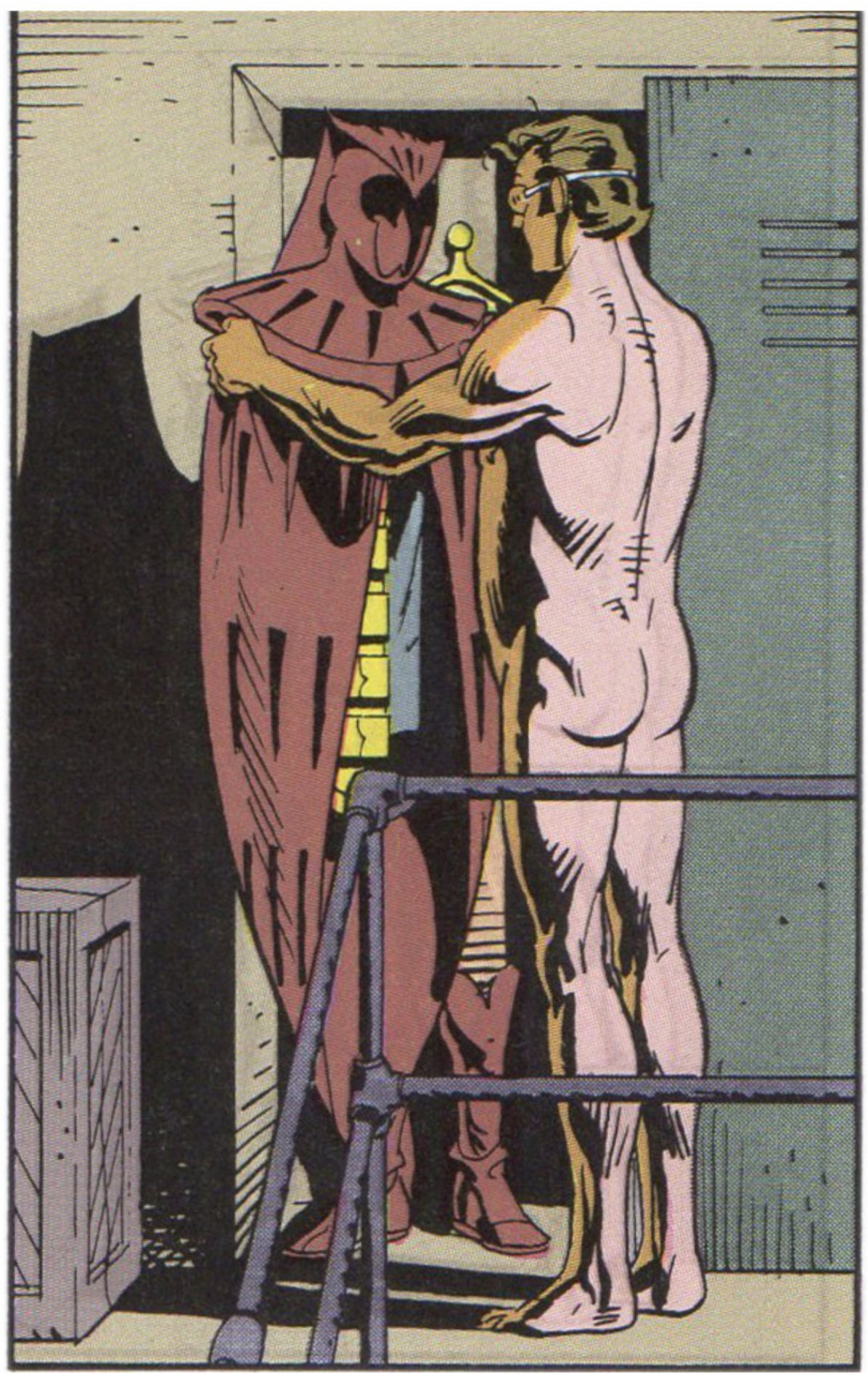

FIG. 27. Watchmen. Alan Moore y Dave Gibbons (1986-87). Cap. VII, p. 20. 
¡Qué maravilloso ejemplo de malicia narrativa! Alan Moore no se conforma con impedir la erección de Dan Dreiberg. Le humilla comparándole con la exhibición de Ozymandias y hace que la voz de la televisión se burle de sus tristes esfuerzos. Por si fuera poco, la rejilla de nueve viñetas se acomoda para enfatizar la humillación: Ozymandias desplaza a Dan hacia la subtrama. El fracaso es tan absoluto - físico, simbólico y estructural- que los lectores sentimos que Dreiberg está al límite de su resistencia psicológica. Necesita recuperar su confianza. Necesita recuperar al Búho.

\section{Conclusión}

Creo sinceramente que la dedicación casi exclusiva de la didáctica a las cuestiones gráficas está relacionada con las características de los estudios del cómic. Sabemos más sobre la semiología y hermenéutica de la narración gráfica que sobre las decisiones concretas y específicas que deben abordar guionistas y dibujantes en su trabajo pero, lamentablemente, los manuales prescinden de lo segundo sin hacerse eco de lo primero. Incluso un manual realizado por autores de gran valía como el Drawing Words Eं Writing Pictures de Matt Madden y Jessica Abel ignora por completo lo que la antigua prescriptiva denominaba "arte del estilo". El manual de Madden y Abel dedica apenas 3 páginas — sobre un total de 282- a la construcción del guión y otras 3 a la narrativa. En este sentido, no soportan la comparación con cualquier manual de cine o de literatura. No hace falta referirnos a lecciones magistrales como las de Eisenstein, Henry James, Edith Warthon o Tarkovski; incluso lecciones tan vulgarizadas como las de Syd Field o las de los talleres de Gotham se ocupan ampliamente de todas las decisiones que de afrontar el artista narrativo y, más aún, recogen, implícita o explícitamente, la tradición teórica de su campo de especialización.

Espero que este artículo haya contribuido, cuando menos, a destacar la indisoluble relación entre forma y contenido en la escritura de la narración gráfica, y que los deméritos del análisis se atribuyan íntegros al autor y no al enfoque. Creo que un giro estilístico en los estudios del cómic sería positivo para su teoría y didáctica. Al fin y al cabo, situar en el foco de la investigación las decisiones artísticas de los autores y los recursos expresivos a su disposición no puede resultar más que beneficioso para la comprensión, desarrollo y expansión de este medio. 


\section{Bibliografía}

Alonso, D. Poesía española. Ensayo de métodos y límites estilísticos. Madrid, Editorial Gredos, 1951.

Aristóteles. Retórica, Madrid, Editorial Gredos, 1999.

Arnheim, R. El cine como arte. Barcelona, Paidós Ibérica, 1986.

Baetens, J. "Graphic Novels: Literature Without Text?" en English Language Notes, no 46, vol. 2 (2008), disponible on line en http://racomics.pbworks.com/f/GN+Literature+Without+Text. pdf

BALÁzs, B. Theory of the Film: character and growth of a new art. Londres Dennis Dobson Limited, 1952.

Burch, N. Praxis del cine. Madrid, Editorial Fundamentos, 2003.

Corn, N. "Navigating comics: an empirical and theoretical approach to strategies of reading comic page layouts" en Front. Psychol. 4:186 (2013), disponible on line en http://journal.frontiersin.org/Journal/10.3389/fpsyg.2013.00186/full

Eisenstein, S. M. "El principio cinematográfico y el ideograma” en Eisenstein, S.M., Teoría y técnica cinematográficas, Madrid, RIALP, 2002.

Flynn, T. Discovering the Literary Relevance of Watchmen: A Review of the Graphic Novel's Philosophical Themes. Lynchburg, Liberty University, 2012, disponible on line en http://digitalcommons.liberty.edu/cgi/viewcontent.cgi?article $=1282 \&$ context=honors

James, H. “El arte de la ficción” en El futuro de la novela, Madrid, Taurus, 1975.

Marín, R. W de Watchmen. Palma de Mallorca, Dolmen Editorial, 2009.

Miettinen, M. "Framing A Fearful Symmetry: Narratological Aspects in Alan Moore's Watchmen", MA Thesis, Universidad de Tampere, 2006, disponible on line en http://www. sarjakuvaseura.fi/files/gradut/gradu01452.pdf?phpMyAdmin=ec7bd4f83c157e3e90578 $\underline{8 \mathrm{e} 10 \mathrm{cceac} 09}$

Mitry, J. La semiología, en tela de juicio. Madrid, Akal, 1990.

Morgan, H. Principes des littératures dessinées. Angoulême, Éditions de l'An 2, 2003.

Moore, A. y Gibbons, D. Watchmen. Barcelona, Norma Editorial, 2000.

Pérez, P. "No me gusta llamar la atención demasiado sobre el dibujo" en Con C de Arte, 18 de Octubre de 2007, disponible on line en http://concdearte.blogspot.com.es/2007/10/prefierono-llamar-demasiado-la-atencin.html (Página web consultada en marzo de 2014)

Stevenson, R.L. El arte de escribir. Santa Cruz de Tenerife, Artemisa Ediciones, 2006. 
Strobel, E. Watchmen as a work of literature. Oregón, Scholars Archive.

Van Ness, S.J. Watchmen as Literature: A Critical Study of the Graphic Novel. Carolina del Norte, McFarland, 2010.

VV. AA. Radiografías de una explosión: Doce aproximaciones criticas a Watchmen. Madrid, Modernito Books, 2013.

Warthon, E. El arte de la ficción. Palma de Mallorca, El Barquero, 2012. 